\title{
Intestinal microbiota in human health and disease: the impact of probiotics
}

\author{
Jacoline Gerritsen • Hauke Smidt • Ger T. Rijkers • \\ Willem M. de Vos
}

Received: 4 February 2011/Accepted: 20 April 2011/Published online: 27 May 2011

(C) The Author(s) 2011. This article is published with open access at Springerlink.com

\begin{abstract}
The complex communities of microorganisms that colonise the human gastrointestinal tract play an important role in human health. The development of culture-independent molecular techniques has provided new insights in the composition and diversity of the intestinal microbiota. Here, we summarise the present state of the art on the intestinal microbiota with specific attention for the application of high-throughput functional microbiomic approaches to determine the contribution of the intestinal microbiota to human health. Moreover, we review the association between dysbiosis of the microbiota and both intestinal and extra-intestinal diseases. Finally, we discuss the potential of probiotic microorganism to modulate the intestinal microbiota and thereby contribute to health and well-being. The effects of probiotic consumption on the intestinal microbiota are addressed, as well as the development of tailor-made probiotics designed for specific aberrations that are associated with microbial dysbiosis.
\end{abstract}

J. Gerritsen $(\varangle) \cdot$ H. Smidt · W. M. de Vos

Laboratory of Microbiology, Wageningen University,

Dreijenplein 10, 6703 HB Wageningen, The Netherlands

e-mail: jacoline.gerritsen@wur.nl

J. Gerritsen

Winclove Bio Industries B.V., Amsterdam, The Netherlands

G. T. Rijkers

Department of Medical Microbiology and Immunology,

St. Antonius Hospital, Nieuwegein, The Netherlands

G. T. Rijkers

Department of Operating Rooms, University Medical Center St. Radboud, Nijmegen, The Netherlands

W. M. de Vos

Departments of Microbiology and Immunology and Veterinary Biosciences, University of Helsinki, Helsinki, Finland
Keywords Diversity $\cdot$ Dysbiosis $\cdot$ Host-microbe interactions $\cdot$ Intestinal microbiota $\cdot$ Probiotics

\section{Introduction}

It is known for over three decades that the human body contains tenfold more microbial cells $\left(10^{14}\right)$ than human cells (Savage 1977). These microorganisms colonise practically every surface of the human body that is exposed to the external environment, including the skin, oral cavity, respiratory, urogenital and gastrointestinal tract. Of these body sites, the gastrointestinal (GI) tract is by far the most densely colonised organ. The complex community of microorganisms residing in or passing through the GI tract is referred to as the intestinal microbiota.

The intestinal microbiota plays a role in metabolic, nutritional, physiological and immunological processes in the human body. It exerts important metabolic activities by extracting energy from otherwise indigestible dietary polysaccharides such as resistant starch and dietary fibres. These metabolic activities also lead to the production of important nutrients, such as short-chain fatty acids (SCFA), vitamins (e.g. vitamin K, vitamin B12 and folic acid) and amino acids, which humans are unable to produce themselves (Hamer et al. 2008; Wong et al. 2006). In addition, the intestinal microbiota participates in the defence against pathogens by mechanisms such as colonisation resistance and production of antimicrobial compounds. Furthermore, the intestinal microbiota is involved in the development, maturation and maintenance of the GI sensory and motoric functions, the intestinal barrier and the mucosal immune system. These are just a few examples of the functional contributions of the intestinal microbiota to human health, a subject that is regularly reviewed (Barbara et al. 2005; 
Cerf-Bensussan and Gaboriau-Routhiau 2010; O'Hara and Shanahan 2006; Sekirov et al. 2010; Zoetendal et al. 2008).

In recent years, a sharp increase is seen in the number of publications addressing the intestinal microbiota. They have provided various lines of evidence supporting a close link between the intestinal microbiota and human health. This review aims to summarise the current knowledge on the composition and diversity of the intestinal microbiota. In addition, it is discussed how new molecular approaches have provided novel insights towards the phylogenetic and functional characterisation of the intestinal microbiota. Furthermore, recent insights on the link between the intestinal microbiota and human health are provided. Finally, an overview is presented of ways to modulate the intestinal microbiota with specific attention for the use of probiotics, defined as live microorganisms which, when administered in adequate amounts, confer a health benefit on the host (FAO/WHO 2002).

\section{Microbial diversity in the GI tract}

The GI tract is a complex and dynamic ecosystem containing a diverse collection of microorganisms. These microorganisms are either resident members of the intestinal microbiota or transient passengers introduced from the environment, for example by the regularly influx of microorganisms by the intake of food.

\section{Compositional diversity of the intestinal microbiota}

The intestinal microbiota can be described in richness ('who is present') and evenness ('with how many are they present') that together form the ecological terms of diversity. If applied at the species-level, richness describes the number of species present in a specific ecosystem, not taking into account their relative abundance. This contrasts with evenness, which represents the relative abundance of each species in a specific ecosystem. These definitions are used to describe the microbial diversity in the GI tract.

Up till recently, conventional culture-based methods were used to assess the intestinal microbial diversity. Over 400 bacterial species have been successfully isolated, cultured and characterised from the human GI tract (RajilićStojanović et al. 2007). However, these culture-based methods have proven to be inadequate in determining the true microbial diversity of the intestinal microbiota since a large fraction of the microbiota remains uncultivated. For a more accurate analysis of the compositional diversity of the intestinal microbiota culture-independent approaches have been developed and it has been revealed that the human intestinal microbiota is an even more complex ecosystem than previously expected. Most of these techniques target the highly conserved $16 \mathrm{~S}$ ribosomal RNA (rRNA) gene sequences of bacterial and archaeal microorganisms. Molecular techniques that are used to study the diversity of the intestinal microbiota include quantitative polymerase chain reaction ( $\mathrm{qPCR}$ ), temperature or denaturing gradient gel electrophoresis (TGGE or DGGE), terminal-restriction fragment length polymorphism (T-RFLP) and fluorescent in situ hybridisation (FISH). The latest developments in high-throughput technologies, such as next generation sequencing and phylogenetic micro-arrays, now allow more in-depth analysis of the complete phylogenetic diversity of the intestinal microbiota (Van den Bogert et al. 2011; Zoetendal et al. 2008). Moving beyond the analysis of the variation in the sequence of a single marker gene, it is currently also possible to characterise the complete genetic material obtained from environmental samples such as the GI tract. With the aid of large-scale sequencing approaches these so called metagenomes can be studied and so far several metagenomic inventories of the intestinal microbiota have been reported (Table 1).

Since the first application of culture-independent methods to determine diversity, it has been shown that the composition of the intestinal microbiota varies substantially amongst individuals (Zoetendal et al. 1998). At least

Table 1 Overview of metagenomic studies of the human intestinal microbiota

\begin{tabular}{|c|c|c|c|c|}
\hline $\begin{array}{l}\text { Nationality of } \\
\text { individuals }\end{array}$ & $\begin{array}{l}\text { Number of } \\
\text { individuals }\end{array}$ & Sequencing technology & $\begin{array}{l}\text { Total length of } \\
\text { sequences obtained }(\mathrm{Gb})\end{array}$ & References \\
\hline American & 2 & Sanger & 0.2 & Gill et al. (2006) \\
\hline Japanese & 13 & Sanger & 0.727 & Kurokawa et al. (2007) \\
\hline American & 18 & 454 FLX Titanium & 2.14 & Turnbaugh et al. (2009) \\
\hline European (Danish or Spanish) & 124 & Solexa (Illumina) & 576.7 & MetaHIT Qin et al. (2010) \\
\hline European & 20 & Sanger & 2.6 & Genescope \\
\hline French & 49 & SoliD & 200 & INRA \\
\hline
\end{tabular}


part of this diversity can be attributed to genetic differences amongst hosts. A positive relation between similarity in dominant faecal microbial communities and genetic relatedness of the hosts has been observed (Stewart et al. 2005; Turnbaugh et al. 2009; Zoetendal et al. 2001). It is estimated that more than 1,000 species-level phylotypes can be found in the GI tract of the total human population (Qin et al. 2010; Rajilić-Stojanović et al. 2007). However, the phylogenetic diversity in one individual is much lower, since the intestinal microbiota of each individual only consists of approximately 160 different bacterial species (Qin et al. 2010). This estimation is based on metagenomic analysis using the number of non-redundant genes contained by an average-sized genome. Despite the high species richness and inter-individual variability of the intestinal microbiota, a limited number of bacterial phylotypes is more prevalent amongst individuals and might therefore represent a shared phylogenetic core (Qin et al. 2010; Tap et al. 2009). However, the estimation of the size of the phylogenetic core is dependent on the minimal relative abundance of a given phylotype that can be detected by the molecular approaches deployed. Recent analysis of metagenomic data indicated that there is a high variability in relative abundance (evenness) of core phylotypes amongst individuals (12- to 2,200-fold difference) (Qin et al. 2010). Altogether, these results demonstrate that an accurate estimation of the size of the phylogenetic core is still difficult to make as this is highly dependent on the depth of the analysis.

The vast majority of all microbial cells in the human GI tract are bacteria. At the phylum-level, both culturedependent and independent studies have demonstrated that the majority of the intestinal bacteria belong to two phyla, the Bacteroidetes and the Firmicutes (Mariat et al. 2009). The phylum Bacteroidetes consists of three classes, of which the class Bacteroidetes, containing the well-known genera Bacteroides and Prevotella, is probably the most well studied. The Firmicutes is currently the largest bacterial phylum, which contains more than 200 genera. The majority of the Firmicutes detected in the GI tract fall primarily into two main groups, the Clostridium coccoides group (also known as Clostridium cluster XIVa) and the Clostridium leptum group (also referred to as Clostridium cluster IV) (Collins et al. 1994; Mariat et al. 2009). Both groups contain members of the genera Clostridium, Eubacterium and Ruminococcus that are taxonomically polyphyletic. In addition to the two phyla Bacteroidetes and Firmicutes, also members of other phyla, such as Proteobacteria, Actinobacteria, Fusobacteria, Spirochaetes, Verrucomicrobia and Lentisphaerae, have been detected (Rajilić-Stojanović et al. 2007; Zoetendal et al. 2008).

Although bacteria dominate the GI tract ecosystem, species from the archaeal domain can also be found in the
GI tract, with the methanogens, Methanobrevibacter smithii and Methanosphaera stadtmanae being by far the most dominant archaeal groups (Gill et al. 2006; Mihajlovski et al. 2008). While it was previously assumed that these methanogens were only present in a minor fraction of healthy subjects, application of new DNA isolation methods has led to the observation that they are in fact highly prevalent (Dridi et al. 2009; Salonen et al. 2010b). In addition to bacteria and archaea, eukaryotic microorganisms can also be members of the intestinal microbiota. Culture-independent analysis of the fungal diversity in the GI tract has demonstrated that the majority of the phylotypes belonged to the two fungal phyla Ascomycota (which includes the genera Candida and Saccharomyces) and Basidiomycota (Ott et al. 2008; Scanlan and Marchesi 2008).

Microbial diversity along the GI tract

Host physiology and intestinal microbiota are intimately connected. This is evident from the fact that each distinct anatomical region along the GI tract is characterised by its own physicochemical conditions, and that these changing conditions exert a selective pressure on the microbiota. The physicochemical conditions that influence the composition of the intestinal microbiota include intestinal motility, $\mathrm{pH}$, redox potential, nutrient supplies, host secretions (e.g. hydrochloric acid, digestive enzymes, bile and mucus), and the presence of an intact ileocaecal valve (Booijink et al. 2007). Thus, the GI tract harbours many distinct niches, each containing a different microbial ecosystem that varies according to the location within the GI tract. This is already demonstrated by the fact that the microbial density increases along the GI tract. Per gram of intestinal content, the microbial density increases from $10^{1}-10^{4}$ microbial cells in the stomach and duodenum, $10^{4}-10^{8}$ cells in the jejunum and ileum, to $10^{10}-10^{12}$ cells in the colon and faeces (Booijink et al. 2007; Dethlefsen et al. 2006). Despite the fact that it is well known that the intestinal microbiota is not homogeneously distributed within the GI tract, it is still largely unknown how the diversity varies in the different niches along the GI tract ("who is present where').

By far, the most detailed knowledge is available with respect to the microbial composition of faeces. This is mainly because faecal material can be collected noninvasively and contains a large biomass of microbial cells. However, as it is increasingly acknowledged that the composition of microbiota differs significantly in the different niches, more efforts are undertaken to determine the spatio-temporal dynamics of the microbial diversity along the whole GI tract (Zoetendal et al. 2002). The large intestine has a rather uniform composition of luminal 
intestinal microorganisms, and faecal material seems to represent the colonic microbiota composition best (Eckburg et al. 2005). In contrast, there is only limited insight in the composition of the microbiota that resides in the small intestine. Especially the lower part of the small intestine, the ileum, has received minimal attention, mainly due to sampling difficulties caused by the inaccessibility of this region (Booijink et al. 2007). The composition of the small intestinal microbiota is largely influenced by a combination of gastric acid, bile and pancreatic secretions that enter the GI tract in the duodenum, and which together create a harsh environment for most microorganisms (Booijink et al. 2007). Hence, compared with other regions, few microorganisms are able to inhabit the upper part of the GI tract. In addition, the antegrade peristaltic movements as part of the migrating motor complex (MMC) ensure a relatively short passage time through the small intestine (3-5 h) by pushing the microbiota towards the large intestine, thus leaving limited time for microorganisms to replicate and increase in numbers (Booijink et al. 2007). The short passage time allows transitioning bacteria to retain viability. Furthermore, cellular enzymes such as glutamate decarboxylase and bile resistance systems offer protection against the low $\mathrm{pH}$ and bile salts encountered in this upper part of the GI tract, respectively (Audia et al. 2001; Merritt and Donaldson 2009).

The small intestine is the part of the GI tract where most of the host enzymatic digestion of the food occurs. The products of these digestive activities are absorbed in more distal parts of the small intestine, the jejunum and especially the ileum. The conditions in the ileum are more favourable for microbial growth compared with the proximal part of the small intestine, as for example the $\mathrm{pH}$ is less acidic and bile acids are reabsorbed. Therefore, the number of microorganisms in the ileum can be higher compared with the duodenum (Booijink et al. 2007).

Most of the knowledge about the small intestinal microbiota has been derived from studies with ileal biopsies collected during surgical intervention (Ahmed et al. 2007; Baumgart et al. 2007; Wang et al. 2003, 2005; Willing et al. 2009) or from samples obtained from elderly individuals at autopsy (Hayashi et al. 2005). In addition, ileal effluent from ileostomy patients has been used to study the diversity of the luminal microbiota of the human ileum (Booijink et al. 2010; Hartman et al. 2009). It was shown that the composition of the microbiota in ileostomy effluent clearly differs from that of the faecal microbiota. Compared with faecal microbiota, ileostomy effluent microbiota is less diverse and less stable, since large fluctuations in ileal microbiota profiles per individual were observed over time (Booijink et al. 2010). One of the main findings of this study by Booijink and colleagues was that ileostomy effluent showed a higher relative abundance of species within the orders Lactobacillales and Clostridiales, especially Veillonella- and Streptococcus-related phylotypes (Booijink et al. 2010). In addition, species belonging to Clostridium cluster I were detected in high levels, in contrast with the reduced levels of species belonging to the Bacteroidetes and Clostridium clusters III, IV and XIVa. More recently, it was demonstrated that the microbiota composition of ileostomy effluent, which is characterised by an abundance in Streptococcus and Veillonella species, is more similar to the proximal small intestinal microbiota and clearly differs from that of the ileum (Zoetendal et al. 2011).

In addition to the variation in microbial composition along the GI tract, the microbiota present in the intestinal lumen also differs significantly from that attached to and imbedded in the intestinal mucus layer. Since mucosaassociated microorganisms live in close contact with host cells, it is likely they execute different functions within the GI ecosystem compared with luminal microorganisms. Several studies have reported a significant difference in dominant microbial community composition between colonic biopsies and faecal samples in humans (Eckburg et al. 2005; Lepage et al. 2005; Zoetendal et al. 2002). It should be kept in mind, however, that in these studies colonic biopsies were obtained from humans undergoing standard colonoscopy, which in general is preceded by a laxative preparation in order to clean the GI tract. The influence of this procedure on the luminal and mucosaassociated microbiota is still largely unknown (Mai et al. 2006).

Animal models could provide a means to study both the microbial composition along the GI tract as well as the difference in luminal and mucosa-associated microbiota, without the need for physiological alterations during sampling. It has been demonstrated in rodents that intestinal microorganisms are able to survive and even proliferate in the outer loose mucus layer since the glycans present in this layer are accessible as energy source for these microorganisms (Kim and Ho 2010; Johansson et al. 2010). In contrast, the inner stratified firmly attached mucus layer probably prevents the intestinal bacteria from coming in contact with the colonic epithelial cells (Johansson et al. 2008). The organisation of the mucus layers varies amongst the different parts of the GI tract, as it has been observed that the mucus layers in the stomach and the colon are well defined, in contrast to the small intestine where the mucus is less evenly distributed (Atuma et al. 2001; Johansson et al. 2010). Most likely, such differences in mucus layer organisation will be associated with variation in the mucosa-associated microbiota along the GI tract. A recent study in mice has shown that the dominant microbiota composition of proximal colonic mucosa-associated and faecal microbiota are very similar to each other, but differ 
both significantly from distal colonic mucosa-associated samples (Wang et al. 2010). In addition, the study demonstrated that the region-specific mucosa-associated microbiota determines the region-specific expression of host genes, in this case of genes encoding Toll-like receptors (TLRs).

Due to the application of culture-independent molecular approaches, our knowledge of the intestinal microbiota has been advanced significantly (Zoetendal et al. 2006). Yet, a complete description of the microbial diversity along the human GI tract cannot be given at this moment. Future research should include more samples from the various distinct niches along the GI tract, which nowadays can be collected using minimally invasive methods and which can be deeply analysed using high-throughput technologies.

\section{Functional diversity of the intestinal microbiota}

Recently, the collective genome of the human intestinal microbiota (the human intestinal microbiome) was estimated to contain 3.3 million microbial genes, which is $\sim 150$ times more genes than the human genome (Qin et al. 2010). The presence of this wide array of genes in addition to our own genome, suggests that a profound influence of intestinal microorganisms on the human body can be expected. This means that meaningful information related to human health does not only originate from insights in the compositional diversity ('who is present', 'with how many are they present' and 'who is present where'), but can also be derived from knowledge on the function of the microbiota ("what are they doing'). The extent to which the intestinal microbiota is able to expand the metabolic, nutritional, physiological and immunological functions the host is able to perform, is still largely unknown. To address this question, metagenomic studies can provide information on the diversity of the genes encoded by the intestinal microbiota. Recently, it was calculated that almost $40 \%$ of the microbial genes present in each human individual were shared with at least half of the human individuals in the studied cohort. These data provide evidence for the existence of a functional core (core microbiome) (Qin et al. 2010). Since functional redundancy within members of the intestinal microbiota exists, there is the possibility that the phylogenetic core does not fully correspond to the functional core (Zoetendal et al. 2008). The functional core may contain shared metabolic functions (e.g. degradation of sugar monomers, production of vitamins or butyrate formation) as well as sequential pathways which would, respectively, restrict or expand functional diversity irrespective of phylogenetic diversity.

A main focus of current research is to understand the functional contribution of the human intestinal microbiota to the host. Function-driven metagenomics is a first step in assessing the functional capacity of the intestinal microbiota. A prediction of the functional capacity can originate from the metagenome by comparing the assembled sequences to reference databases, such as the COG (clusters of orthologous groups) and KEGG (Kyoto encyclopedia of genes and genomes) databases. Moreover, function-driven metagenomics can be applied to assign a function to predicted gene products and can even contribute to gene discovery (Tasse et al. 2010; Cowan et al. 2005). The first metagenomic studies have demonstrated that, compared with the human genome, the human intestinal microbiome is highly enriched for COG and KEGG categories involved in metabolism (Gill et al. 2006; Kurokawa et al. 2007; Turnbaugh et al. 2009). Pathways involved in metabolism of energy, amino acids, nucleotides, carbohydrates, cofactors and vitamins, terpenoids and polyketides, and the biosynthesis of secondary metabolites are highly represented in the human microbiome. These pathways not only allow the microbes to generate energy, to grow and proliferate, but also to influence the host. Some of the metabolites are being taken away from the host while other ones are provided (e.g. SCFA, vitamins, gases). Overall, the (metabolic) interaction between microbes and host is beneficial for both parties. Future studies should provide data to further establish and detail the functional contribution of the intestinal microbiota to the metabolic capacity of the host.

Metagenomic studies provide only insight in the genetic potential of the intestinal microbiota and do not demonstrate its true functional contribution to the maintenance of health and well-being (Zoetendal et al. 2008). In order to obtain insights in the in situ expression of genes encoded by the intestinal microbiome, other functional microbiomic approaches, such as metatranscriptomics, metaproteomics and metabolomics are required. A recent example of a metatranscriptomic approach to study the intestinal microbiota is provided by the study performed by Booijink et al. (2010). These authors were able to demonstrate that the gene expression of the human faecal microbiota is subject-specific and enriched for genes involved in (carbohydrate) metabolism. Gosalbes and colleagues also applied a metatranscriptomic approach to study the functionality of the faecal microbiota of healthy volunteers (Gosalbes et al. 2011). Remarkably, more rRNA genes were observed than protein-encoding genes. Analysis of the latter showed a uniform functional pattern in carbohydrate metabolism, energy production and synthesis of cellular components as well as regulatory elements (small RNAs). More specific information has been derived from the metatranscriptomic analysis of bifidobacteria in early life that revealed marked differences between breast-fed and formula-fed infants. Moreover, the specific expression of genes involved in the degradation of human-derived sugars and vitamins such as folic acid biosynthesis testify for the health impacting function of intestinal bifidobacteria (Klaassens et al. 2009). Furthermore, metaproteomics 
approaches have been applied to investigate faecal samples obtained from human infants (Klaassens et al. 2007) and adults (Rooijers et al. 2011; Verberkmoes et al. 2009). In human adults, it was demonstrated that the faecal metaproteome is enriched in proteins belonging to the $\mathrm{COG}$ categories involved in translation, energy production and carbohydrate metabolism (Verberkmoes et al. 2009). Compared with metatranscriptomics and metaproteomics approaches, metabolomic approaches have up to this date been applied more frequently, using NMR spectroscopy and mass spectroscopy in conjunction with computational multivariate analysis (Nicholson and Lindon 2008). A recent study by Martin and colleagues demonstrates that metabolic profiling can be used for studying nutrientmicrobiota relations by examining the effects of dietary intervention on the presence of faecal metabolites (Martin et al. 2010). A variety of systemic diseases such as hypertension (Holmes et al. 2008) and diabetes (Dumas et al. 2007) appear to be directly influenced by microbial metabolism in model animals and human (Kinross et al. 2011). The metabolic pathways that are involved in drug metabolism are also influenced by the intestinal microbiota in an in vitro system (Aura et al. 2011).

Altogether, functional microbiomic approaches can be applied to examine microbial gene expression and to establish the effects of microbial gene products on the host. However, up to this date it is difficult to connect functionality to the presence of individual microbial species in the human GI tract. In order to link specific sets of genes to the presence of distinct microbial species, complete microbial genome sequences will be needed. Several independent research consortia have taken up the effort to sequence the genomes of hundreds of bacterial strains, which together will form a catalogue of reference genomes from the human microbiota. Recently, the initial sequencing of 178 reference genomes was reported and the first results of comparative genomic analysis of these sequences provided important insight into the inter-strain diversity of bacterial genomes (Nelson et al. 2010). Large-scale functional microbiomic analyses are needed to fully understand the impact of the human microbiome on the host. This means that a larger number of samples, deeper sequencing, longer sequence reads and more extensive comparative analyses are needed. Integration of all these microbiomic approaches will help to define the functional contribution of each individual microbial phylotype in the human GI tract to the health status of the host.

\section{Changes in composition and diversity of the intestinal microbiota are related to disease}

The type and number of microbial species that persist and colonise the GI tract is not determined by chance, but by a combination of factors including but not limited to the inflammatory state of the host, diet, host genetics, and environmental factors (Buddington and Sangild 2011; Cerf-Bensussan and Gaboriau-Routhiau 2010; Hansen et al. 2010; Musso et al. 2010). This means that the host itself influences the composition of the intestinal microbiota. However, the relative impact of these factors on the intestinal microbiota is still largely unknown.

The intestinal microbiota and the host have coevolved (Ley et al. 2008). Human evolution has taken place amidst a world of microorganisms. Symbiotic microorganisms have occupied the niches offered by the gastrointestinal tract and probably adapted to the local circumstances. This in turn may have influenced human evolution in terms of metabolic and nutritional requirements. Ultimately, man depends on its intestinal microbiota for a number of vital functions and thus these intestinal microorganisms may contribute to health. It is, however, difficult to describe the precise impact of the intestinal microbiota on human health and the involvement in human disease.

Perturbation of the microbiota composition, also known as dysbiosis, has been recognised in various diseases, of which many are associated with the GI tract. However, before dysbiosis can be established, the composition of a healthy 'normal' microbiota has to be defined. Yet, the definition of a healthy microbiota is not easy to give. From an operational point of view it could be stated that a healthy intestinal microbiota is the microbiota composition as it can be found in healthy individuals. For practical reasons, the phylogenetic characterisation of the microbiota of diseased individuals in comparison with apparently healthy individuals is, at this moment, the main approach to study changes in composition of the intestinal microbiota in relation to disease. However, since there are substantial inter-individual and intraindividual variations in the composition of the intestinal microbiota, it is difficult to establish the precise relations between human health and the presence and relative abundance of specific microbial communities. In the future, specific changes in compositional diversity, or even functional diversity, may be applied as biomarkers for health or specific diseases. It must be noted, however, that it is questionable whether changes in phylogenetic composition are really cause or consequence of a given disease.

A role for the intestinal microbiota in the pathogenesis of several diseases and disorders has been suggested. Intensively studied examples for which dysbiosis of the intestinal microbiota has been described, include inflammatory bowel disease (IBD), irritable bowel syndrome (IBS) and obesity, which will be discussed in-depth in this part of the review. 
The microbial composition at different stages of life and its relation to health

The intestinal microbiota of healthy adult individuals is relatively stable over time (Costello et al. 2009; Franks et al. 1998; Vanhoutte et al. 2004; Zoetendal et al. 1998). However, intra-individual fluctuations occur due to environmental changes and pathological events. In addition, substantial changes in the composition of intestinal microbiota occur at both ends of life, in infants and elderly individuals (Tiihonen et al. 2010; Vael and Desager 2009). Since alterations in the microbial composition are recognised to be of influence on human health, the interest in the development and composition of the microbiota of infant and elderly humans has significantly increased in the last years.

It is widely accepted that microbial colonisation of the GI tract starts during and directly after birth when neonates are exposed to bacteria that are derived from the mother and the surrounding environment (Adlerberth and Wold 2009; Mackie et al. 1999). Yet, the human foetal environment is not completely microbiologically sterile and there are indications that non-pathological in utero exposure of the foetus to intestinal bacteria or bacterial DNA frequently occurs (Pettker et al. 2007; Satokari et al. 2009). In addition, the isolation of bacteria from the meconium (the first stool of the neonate), umbilical cord blood and amniotic fluid of healthy neonates has been reported (Jiménez et al. 2005, 2008). Postnatal colonisation of the GI tract is highly variable amongst neonates and is influenced by several factors including mode of delivery, type of infant feeding, gestational age, infant hospitalisation and antibiotic use (Penders et al. 2006). It is, however, still unclear how each of these factors exactly influences the infant microbial diversity and how this is related to health. A disturbed development of the infant microbiota has been associated with the development of disease later in life (Vael and Desager 2009). For example, associations have been made between dysbiosis in infants and the later development of childhood obesity (Collado et al. 2008b; Kalliomäki et al. 2008) and atopic and allergic diseases (Björkstén et al. 2001; Kalliomäki et al. 2001; Penders et al. 2007; Sjögren et al. 2009; Wang et al. 2008).

Several culture-independent studies have shown that there is a large inter-individual variability amongst infants in the development of the microbiota (Favier et al. 2002; Palmer et al. 2007; Penders et al. 2006; Roger et al. 2010). In addition, it has been demonstrated that the infant microbiota is highly dynamic and develops in a step-wise fashion with an increase in diversity over time (Palmer et al. 2007; Roger et al. 2010). An important stage in the colonisation of the GI tract of infants is the period in which the infants feed on the milk they receive either by breastfeeding or by infant-formula feeding. During this period, the faecal microbiota of infants consists mainly of bifidobacteria (Roger and McCartney 2010; Roger et al. 2010). Some bifidobacteria are highly adapted to the digestion of the oligosaccharides present in human milk (Zivkovic et al. 2010). The infant intestinal microbiota contains a relatively low diversity in Bifidobacterium populations; B. breve, B. bifidum and B. longum subsp. infantis are the most common Bifidobacterium species (Roger et al. 2010). Compared with breast-fed infants, the intestinal microbiota of formula-fed infants is characterised by less diverse Bifidobacterium populations (Roger et al. 2010) and more complex communities of Clostridia, Enterobacteriaceae, Bacteroides and Enterococcus (Harmsen et al. 2000; Penders et al. 2006). The introduction of solid food (weaning) marks an increase in microbial diversity and changes in the microbial composition towards an adult microbiota (Koenig et al. 2010). For example, dominant Bifidobacterium populations change; B. adolescentis, B. catenulatum and B. longum subsp. longum are more abundantly present in the adult microbiota (Matsuki et al. 2004). The successive shifts of different microbial communities within the first years of life ultimately result in the development of an adult-like microbiota.

In the elderly (usually defined as people over the age of $65)$, there are major physiological changes that have an impact on the composition and the functionality of the intestinal microbiota (Tiihonen et al. 2010; Woodmansey 2007). Many elderly humans suffer from decreased intestinal motility, which can result in prolonged intestinal transit time and faecal retention. Age-related changes, such as decreased senses for smell and taste, dental decay and swallowing difficulties can lead to narrowing of the nutritional intake and even malnutrition. In addition, the age-related gradual deterioration of the immune system (immunosenescence) is associated with changes in intestinal microbiota composition (Schiffrin et al. 2010). Furthermore, the increased use of laxatives, antibiotics and other medication in elderly individuals will affect intestinal microbiota composition.

Culture-independent studies have demonstrated that the composition of the intestinal microbiota significantly changes with age (Bartosch et al. 2004; Mariat et al. 2009; Mueller et al. 2006; Zwielehner et al. 2009). Recently, high-throughput methods have been applied to study the changes in the intestinal microbiota of elderly individuals. Biagi and colleagues have used the HITChip, a phylogenetic microarray specifically designed to study the human GI tract microbiota, to compare the intestinal microbiota composition of young adults with that of elderly individuals and centenarians. It was demonstrated that especially the microbiota of centenarians showed significant differences compared with microbiota composition of the other 
two age groups (Biagi et al. 2010). The microbiota of centenarians was characterised by low species-level diversity, specific changes in Firmicutes subpopulations, enrichment in Proteobacteria and a decrease in bifidobacteria. In addition, high-throughput next generation sequencing has been used by Claesson and colleagues to study the composition, variability and temporal stability of the intestinal microbiota of the elderly (Claesson et al. 2010). They observed that the faecal microbiota of elderly individuals was relatively stable over a 3 month period in the majority of the subjects. However, compared with younger control subjects, the microbiota of the elderly was characterised by a high inter-individual variation in microbiota composition, also at phylum level. The relative abundance of the Firmicutes varied between $8 \%$ and $80 \%$, whereas the Bacteroidetes levels varied between $14 \%$ and $92 \%$. Furthermore, it was found that in the majority of the elderly subjects the microbiota was characterised by a higher Bacteroidetes/Firmicutes ratio compared with that observed in younger adults. In addition, distinct differences were seen in Proteobacteria, Actinobacteria and Clostridium populations between young and older adults. With respect to human health, associations have been found between microbiota composition and frailty in elderly individuals (Van Tongeren et al. 2005). In frail elderly persons, a significant reduction in the number of lactobacilli, Faecalibacterium prausnitzii and BacteroidesPrevotella groups was seen. In contrast, the number of Enterobacteriaceae was significantly higher. The number of studies that have focused on the age-related differences in intestinal microbiota composition is still limited. In general, they suggest that maintenance of (microbial) homeostasis in the GI tract is essential for healthy ageing.

\section{Microbial diversity and IBS}

IBS is a functional bowel disorder which is characterised by recurrent abdominal pain or discomfort, irregular bowel movements and disordered stool patterns such as constipation or diarrhoea (Longstreth et al. 2006). The occurrence of these symptoms, however, can vary from person to person. The aetiology of IBS is probably complex and still not well understood. Several factors are thought to be involved in IBS and may include altered GI motility, visceral hypersensitivity, low-grade inflammation, and psychosocial (anxiety and depression), genetic and dietary factors (Chang and Talley 2011; Karantanos et al. 2010).

Several studies, using both culture-dependent and independent methods, have demonstrated an association between IBS and dysbiosis of the intestinal microbiota (Table 2). In general, faecal material has been used to study dysbiosis in IBS patients. However, more recently also duodenal (Kerckhoffs et al. 2009, 2010) and colonic
(Carroll et al. 2010; Codling et al. 2010) biopsies have been used to study the mucosa-associated microbiota. Most studies aimed to show changes in the predominant microbial communities, however, in some cases the focus was more on specific microbial groups. Quantitative differences in microbiota composition, even for specific microbial groups, have been observed in IBD patients compared with healthy individuals. However, the results of the various studies are inconsistent and no consensus has been reached on the association between specific microbial groups and IBS, notably as the power of the studies was low and the depth of the analysis was limited (Salonen et al. 2010a). At the functional level, some studies have demonstrated altered colonic fermentation patterns and increased gas production in IBS patients (Koide et al. 2000; Mortensen et al. 1987; Tana et al. 2010; Treem et al. 1996). However, these results have not yet been confirmed in other studies at the molecular level.

In most of the studies, IBS patients have been classified into different subtypes based on Rome II criteria for IBS: diarrhoea-predominant IBS (IBS-D), constipationpredominant IBS (IBS-C) or a mixed type of IBS with alternating stool patterns (IBS-A). Distinct changes in microbiota composition have been observed in the different IBS subtypes compared with healthy individuals (Malinen et al. 2005; Maukonen et al. 2006; Lyra et al. 2009). It appears that the intestinal microbiota of IBS-D patients deviates the most from that of healthy individuals (Carroll et al. 2010; Krogius-Kurikka et al. 2009). These data demonstrate the relevance of clinical subtyping of IBS patients when analysing the intestinal microbiota. So far, however, the results from the studies which have applied IBS subtyping have also not shown uniform changes in microbial composition (Salonen et al. 2010a).

\section{Microbial diversity and IBD}

IBD is a collective name for chronic inflammatory disorders of the GI tract, of which Crohn's disease (CD) and ulcerative colitis (UC) are the most prevalent forms. These are both chronic and relapsing diseases that affect the intestinal mucosa. For both CD and UC, the exact aetiology is still not clear, however, it is has been suggested that an aberrant immune response directed against intestinal microbial antigens is involved (Hansen et al. 2010; Sartor 2008; Sokol and Seksik 2010). CD affects the whole GI tract and is characterised by discontinuous inflammation of the epithelial lining and deep ulcers. UC on the other hand is restricted to the colon and the rectum and is characterised by a continuous mucosal inflammation and superficial ulcers.

During the last decade, numerous culture-independent studies have compared the intestinal microbiota composition of IBD patients with that of healthy individuals 
Table 2 Overview of human studies that demonstrate an association between IBS and compositional dysbiosis of the intestinal microbiota determined with culture-independent methods

\begin{tabular}{|c|c|c|c|}
\hline Study material & Population & Analytical methods & References \\
\hline Faeces (3 time points) & $\begin{array}{l}27 \text { IBS patients } \\
22 \text { Healthy individuals }\end{array}$ & qPCR & Malinen et al. $(2005)^{*}$ \\
\hline Faeces (3 time points) & $\begin{array}{l}26 \text { IBS patients } \\
25 \text { Healthy individuals }\end{array}$ & $\begin{array}{l}\text { Conventional culturing } \\
\text { DGGE } \\
\text { Clone library sequencing (16S) }\end{array}$ & Mättö et al. (2005)* \\
\hline $\begin{array}{l}\text { Biopsies: inflamed and non-inflamed } \\
\text { tissue (ileum, ascending/sigmoid colon) }\end{array}$ & $\begin{array}{l}20 \text { CD patients } \\
20 \text { UC patients } \\
20 \text { Self-limiting colitis patients } \\
20 \text { IBS patients } \\
20 \text { Healthy individuals }\end{array}$ & FISH & Swidsinski et al. (2005) \\
\hline Faeces (2 time points) & $\begin{array}{l}16 \text { IBS patients } \\
16 \text { Healthy individuals }\end{array}$ & $\begin{array}{l}\text { DGGE } \\
\text { TRAC }\end{array}$ & Maukonen et al. (2006)* \\
\hline Faeces & $\begin{array}{l}24 \text { IBS patients } \\
23 \text { Healthy individuals }\end{array}$ & $\begin{array}{l}\mathrm{G}+\mathrm{C} \text { based profiling } \\
\text { Clone library sequencing }(16 \mathrm{~S}) \\
\text { qPCR }\end{array}$ & Kassinen et al. (2007)* \\
\hline $\begin{array}{l}\text { Duodenal biopsies } \\
\text { Faeces }\end{array}$ & $\begin{array}{l}41 \text { IBS patients } \\
26 \text { Healthy individuals }\end{array}$ & $\begin{array}{l}\text { FISH } \\
\text { qPCR }\end{array}$ & Kerckhoffs et al. (2009) \\
\hline Faeces & $\begin{array}{l}10(+2) \text { IBS (only IBS-D) } \\
23 \text { Healthy individuals }\end{array}$ & $\begin{array}{l}\mathrm{G}+\mathrm{C} \text { based profiling } \\
\text { Clone library sequencing }(16 \mathrm{~S}) \\
\text { qPCR }\end{array}$ & Krogius-Kurikka et al. (2009)* \\
\hline Faeces (3 time points) & $\begin{array}{l}20 \text { IBS patients } \\
15 \text { Healthy individuals }\end{array}$ & qPCR & Lyra et al. (2009)* \\
\hline $\begin{array}{l}\text { Colonic biopsies } \\
\text { Faeces }\end{array}$ & $\begin{array}{l}10 \text { IBS patients (only IBS-D) } \\
10 \text { Healthy individuals }\end{array}$ & $\begin{array}{l}\text { Conventional culturing } \\
\text { qPCR }\end{array}$ & Carroll et al. (2010) \\
\hline $\begin{array}{l}\text { Colonic biopsies } \\
\text { Faeces }\end{array}$ & $\begin{array}{l}47 \text { IBS patients } \\
33 \text { Healthy individuals }\end{array}$ & DGGE & Codling et al. (2010) \\
\hline Duodenal biopsies & 37 IBS patients & DGGE & Kerckhoffs et al. (2010) $)^{\#}$ \\
\hline Faeces & 20 Healthy individuals & $\begin{array}{l}\text { Clone library sequencing (16S) } \\
\text { qPCR }\end{array}$ & \\
\hline Faeces & 44 IBS patients & qPCR & Malinen et al. (2010)* \\
\hline Faeces & $\begin{array}{l}26 \text { IBS patients } \\
26 \text { Healthy individuals }\end{array}$ & $\begin{array}{l}\text { Conventional culturing } \\
\text { qPCR } \\
\text { HPLC }\end{array}$ & Tana et al. (2010) \\
\hline
\end{tabular}

All studies have applied Rome II or III criteria to recruit their subjects and categorise them in IBS subtypes. Studies that have used subjects from the same cohort are indicated by $*$ and \#

$D G G E$ denaturing gradient gel electrophoresis, FISH fluorescence in situ hybridisation, HPLC high-performance liquid chromatography, $q P C R$ quantitative polymerase chain reaction, TRAC transcript analysis with the aid of affinity capture

(Table 3). There is increasing evidence that dysbiosis of the intestinal microbiota has a role in the pathogenesis of IBD. Up to this date, however, the phylum-level changes observed in IBD patients have not always been consistent. In general, an overall decrease in microbial diversity and stability of the intestinal microbiota has been observed in IBD patients (Hansen et al. 2010). In addition, a decrease in specific members of the Firmicutes has been reported in IBD patients, which in some cases coincided with an increase in Bacteroidetes and facultative anaerobes such as
Enterobacteriaceae (Hansen et al. 2010). Significant differences exist in the microbiota composition of CD patients compared with UC patients (Frank et al. 2007; Sokol et al. 2006). Recently, Joossens and colleagues identified a set of five bacterial species that characterised the predominant dysbiosis in $\mathrm{CD}$ patients compared with unaffected relatives and healthy individuals (Joossens et al. 2011). These five species are Dialister invisus, an uncharacterised species of Clostridium cluster XIVa, Faecalibacterium prausnitzii, Bifidobacterium adolescentis and Ruminococcus 
Table 3 Overview of human studies that demonstrate an association between IBD and compositional dysbiosis of the intestinal microbiota determined with culture-independent methods

\begin{tabular}{|c|c|c|c|}
\hline Study material & Population & Analytical methods & References \\
\hline Biopsies (terminal ileum, colon) & $\begin{array}{l}12 \mathrm{CD} \text { patients (active disease) } \\
12 \mathrm{UC} \text { patients (active disease) } \\
14 \text { Non-IBD controls }\end{array}$ & FISH & Kleessen et al. (2002) \\
\hline $\begin{array}{l}\text { Biopsies: inflamed and non-inflamed } \\
\text { tissue (ileum, ascending/sigmoid } \\
\text { colon) }\end{array}$ & $\begin{array}{l}28 \text { Self-limiting colitis patients } \\
104 \text { Indeterminate colitis patients } \\
119 \text { UC patients } \\
54 \text { CD patients } \\
40 \text { Non-IBD controls }\end{array}$ & $\begin{array}{l}\text { Conventional culturing } \\
\text { qPCR } \\
\text { FISH }\end{array}$ & Swidsinski et al. (2002) \\
\hline Faeces & $\begin{array}{l}8 \mathrm{CD} \text { patients (active disease) } \\
9 \mathrm{CD} \text { patients (in remission) } \\
16 \text { Healthy individuals }\end{array}$ & $\begin{array}{l}\text { Dot-blot hybridisation } \\
\text { TGGE }\end{array}$ & Seksik et al. (2003) \\
\hline Faeces & $\begin{array}{l}4 \mathrm{CD} \text { patients } \\
4 \text { Healthy controls }\end{array}$ & $\begin{array}{l}\text { Clone library sequencing } \\
(16 \mathrm{~S})\end{array}$ & Mangin et al. (2004) \\
\hline Colonic biopsies: inflamed tissue & $\begin{array}{l}26 \mathrm{CD} \text { patients (active disease) } \\
31 \mathrm{UC} \text { patients (active disease) } \\
15 \text { Inflammatory controls } \\
31 \text { Non-inflammatory controls }\end{array}$ & $\begin{array}{l}\text { SSCP } \\
\text { Clone library sequencing } \\
\quad(16 \mathrm{~S}) \\
\text { qPCR }\end{array}$ & Ott et al. (2004) \\
\hline $\begin{array}{l}\text { Rectal biopsies: inflamed and } \\
\text { non-inflamed tissue }\end{array}$ & $\begin{array}{l}4 \mathrm{CD} \text { patients (active disease) } \\
2 \mathrm{CD} \text { patients (in remission) } \\
14 \mathrm{UC} \text { patients (active disease) } \\
19 \mathrm{UC} \text { patients (in remission) } \\
14 \text { Non-IBD controls }\end{array}$ & FISH & Mylonaki et al. (2005) \\
\hline $\begin{array}{l}\text { Biopsies: inflamed and non-inflamed } \\
\text { tissue } \\
\text { (ileum, ascending/sigmoid colon) }\end{array}$ & $\begin{array}{l}20 \text { CD patients } \\
20 \text { UC patients } \\
20 \text { Self-limiting colitis patients } \\
20 \text { IBS patients } \\
20 \text { Non-IBD controls }\end{array}$ & FISH & Swidsinski et al. (2005) \\
\hline $\begin{array}{l}\text { Biopsies: inflamed and non-inflamed } \\
\text { tissue } \\
\text { (ileum, ascending/transverse/ } \\
\text { descending colon, rectum) }\end{array}$ & $\begin{array}{l}20 \mathrm{CD} \text { patients (active disease) } \\
15 \mathrm{UC} \text { patients (active disease) } \\
14 \text { Non-IBD controls }\end{array}$ & $\begin{array}{l}\text { Clone library sequencing } \\
(16 S) \\
\text { DGGE } \\
\text { qPCR }\end{array}$ & Bibiloni et al. (2006) \\
\hline $\begin{array}{l}\text { Biopsies: inflamed and non-inflamed } \\
\text { tissue } \\
\text { (ileum, transverse/sigmoid colon, } \\
\text { rectum) }\end{array}$ & $\begin{array}{l}6 \text { CD patients } \\
5 \text { UC patients } \\
5 \text { Non-IBD controls }\end{array}$ & $\begin{array}{l}\text { Clone library sequencing } \\
(16 \mathrm{~S})\end{array}$ & Gophna et al. (2006) \\
\hline Faeces & $\begin{array}{l}6 \mathrm{CD} \text { patients (in remission) } \\
6 \text { Healthy individuals }\end{array}$ & $\begin{array}{l}\text { Clone library screening } \\
\text { (metagenome: } 16 \mathrm{~S}) \\
\text { FISH/flow cytometry }\end{array}$ & $\begin{array}{l}\text { Manichanh et al. } \\
(2006)^{*}\end{array}$ \\
\hline $\begin{array}{l}\text { Biopsies: inflamed and non-inflamed } \\
\text { tissue (ileum, ascending/transverse/ } \\
\text { descending/sigmoid colon, rectum) }\end{array}$ & $\begin{array}{l}19 \text { CD patients } \\
2 \text { UC patients } \\
1 \text { Ischemic colitis patient } \\
15 \text { Non-IBD controls }\end{array}$ & $\begin{array}{l}\text { DGGE } \\
\text { 16S rRNA gene sequence } \\
\text { analysis }\end{array}$ & $\begin{array}{l}\text { Martinez-Medina et al. } \\
\text { (2006) }\end{array}$ \\
\hline $\begin{array}{l}\text { Faeces } \\
\text { (several time points) }\end{array}$ & $\begin{array}{l}16 \mathrm{CD} \text { patients } \\
18 \text { Healthy individuals }\end{array}$ & DGGE & Scanlan et al. (2006) \\
\hline
\end{tabular}


Table 3 continued

\begin{tabular}{|c|c|c|c|}
\hline Study material & Population & Analytical methods & References \\
\hline Faeces & $\begin{array}{l}13 \mathrm{CD} \text { patients (active disease) } \\
13 \mathrm{UC} \text { patients (active disease) } \\
5 \text { Infectious colitis patients } \\
13 \text { Healthy individuals }\end{array}$ & FISH/flow cytometry & Sokol et al. (2006) \\
\hline Faeces & $\begin{array}{l}29 \text { UC patients (active disease) } \\
12 \text { UC patients (in remission) } \\
46 \text { Healthy individuals }\end{array}$ & T-RFLP & Andoh et al. (2007) \\
\hline Ileal biopsies & $\begin{array}{l}13 \mathrm{CD} \text { patients (ileum) } \\
8 \mathrm{CD} \text { patients (colon) } \\
7 \text { Non-IBD controls }\end{array}$ & $\begin{array}{l}\text { Clone library sequencing } \\
(16 \mathrm{~S}) \\
\text { qPCR } \\
\text { FISH }\end{array}$ & Baumgart et al. (2007) \\
\hline Biopsies (small intestine and colon) & $\begin{array}{l}68 \text { CD patients } \\
61 \text { UC patients } \\
61 \text { Non-IBD controls }\end{array}$ & $\begin{array}{l}\text { Clone library sequencing } \\
(16 \mathrm{~S}) \\
\text { qPCR }\end{array}$ & Frank et al. (2007) \\
\hline Biopsies (caecum, colon, rectum) & $\begin{array}{l}13 \text { CD patients } \\
19 \text { UC patients } \\
15 \text { Healthy individuals }\end{array}$ & $\begin{array}{l}\text { RISA } \\
\text { Conventional culturing }\end{array}$ & Kotlowski et al. (2007) \\
\hline Faeces & $\begin{array}{l}17 \mathrm{CD} \text { patients (active disease) } \\
17 \mathrm{CD} \text { patients (in remission) } \\
20 \text { Healthy controls }\end{array}$ & T-RFLP & Andoh et al. (2008) \\
\hline Faeces & $\begin{array}{l}10 \text { Twin pairs with } \mathrm{CD} \\
8 \text { Healthy twin pairs }\end{array}$ & $\begin{array}{l}\mathrm{G}+\mathrm{C} \text { profiling } \\
\text { Clone library sequencing } \\
\quad(16 \mathrm{~S}) \\
\text { T-RFLP }\end{array}$ & Dicksved et al. $(2008)^{\dagger}$ \\
\hline $\begin{array}{l}\text { Faeces } \\
\text { (several time points) }\end{array}$ & $\begin{array}{l}16 \text { UC patients (in remission) } \\
8 \text { Healthy controls }\end{array}$ & DGGE & Martinez et al. (2008) \\
\hline $\begin{array}{l}\text { Colonic biopsies } \\
\text { Faeces }\end{array}$ & $\begin{array}{l}15 \mathrm{CD} \text { patients (active disease) } \\
8 \mathrm{CD} \text { patients (in remission) } \\
44 \mathrm{UC} \text { patients (active disease) } \\
29 \mathrm{UC} \text { patients (in remission) }\end{array}$ & $\begin{array}{l}\text { Conventional culturing } \\
\text { qPCR } \\
\text { FISH } \\
\text { HPLC }\end{array}$ & Takaishi et al. (2008) \\
\hline $\begin{array}{l}\text { Rectal biopsies: inflamed and } \\
\text { non-inflamed tissue }\end{array}$ & $\begin{array}{l}9 \text { UC patients (active disease) } \\
11 \text { Non-IBD controls }\end{array}$ & T-RFLP & Nishikawa et al. (2009) \\
\hline Faeces & $\begin{array}{l}22 \mathrm{CD} \text { patients (active disease) } \\
10 \mathrm{CD} \text { patients (in remission) } \\
12 \mathrm{UC} \text { patients (active disease) } \\
4 \text { UC patients (in remission) } \\
8 \text { Infectious colitis patients } \\
27 \text { Healthy individuals }\end{array}$ & qPCR & Sokol et al. $(2009)^{\#}$ \\
\hline $\begin{array}{l}\text { Biopsies (terminal ileum, ascending/ } \\
\text { transverse/descending colon, } \\
\text { rectum) }\end{array}$ & $\begin{array}{l}10 \text { Twin pairs with } C D \\
8 \text { Healthy twin pairs }\end{array}$ & $\begin{array}{l}\text { T-RFLP } \\
\text { Clone library sequencing } \\
\quad(16 S) \\
\text { qPCR }\end{array}$ & Willing et al. (2009) ${ }^{\dagger}$ \\
\hline Faeces & $\begin{array}{l}6 \mathrm{CD} \text { patients (in remission) } \\
6 \text { Healthy individuals }\end{array}$ & $\begin{array}{l}\text { qPCR } \\
\text { Phylogenetic microarray } \\
(16 S)\end{array}$ & Kang et al. $(2010)^{*}$ \\
\hline
\end{tabular}


Table 3 continued

\begin{tabular}{|c|c|c|c|}
\hline Study material & Population & Analytical methods & References \\
\hline Faeces & $\begin{array}{l}4 \text { CD patients (in remission) } \\
21 \text { UC patients (in remission) } \\
14 \text { Healthy individuals }\end{array}$ & $\begin{array}{l}\text { Clone library sequencing } \\
\text { (metagenome) }\end{array}$ & Qin et al. (2010) \\
\hline Faeces & $\begin{array}{l}68 \text { CD patients (in remission) } \\
84 \text { Unaffected relatives } \\
55 \text { Healthy individuals }\end{array}$ & $\begin{array}{l}\text { DGGE } \\
\text { qPCR }\end{array}$ & Joossens et al. (2011) \\
\hline Faeces & $\begin{array}{l}16 \text { CD patients (active disease) } \\
16 \text { Healthy individuals }\end{array}$ & $\begin{array}{l}\text { qPCR } \\
\text { Phylogenetic microarray } \\
(16 S)\end{array}$ & Mondot et al. (2011) \\
\hline $\begin{array}{l}\text { Biopsies: inflamed and non-inflamed } \\
\text { tissue (ileum, ascending/transverse/ } \\
\text { descending/sigmoid colon, rectum) }\end{array}$ & $\begin{array}{l}12 \text { CD patients (active disease) } \\
6 \text { UC patients (active disease) } \\
5 \text { Non-IBD controls }\end{array}$ & $\begin{array}{l}\text { qPCR } \\
\text { Clone library sequencing } \\
(16 \mathrm{~S})\end{array}$ & Walker et al. (2011) \\
\hline
\end{tabular}

Most of the studies used the Crohn's disease activity index (CDAI; for CD) and/or the clinical activity index (CAI; for UC patients) to assess disease activity in the subjects and to define active disease or remission. Studies that have used subjects from the same cohort are indicated by $*$, \# and $\dagger$

$D G G E$ denaturing gradient gel electrophoresis, FISH fluorescence in situ hybridisation, HPLC high-performance liquid chromatography, $q P C R$ quantitative polymerase chain reaction, RISA ribosomal intergenic spacer analysis, SSCP single strand conformation polymorphism, T-RFLP terminal-restriction fragment length polymorphism, $T G G E$ temperature gradient gel electrophoresis

gnavus. Of these species, $F$. prausnitzii has been associated with prolongation of remission in $\mathrm{CD}$ (see also below and Sokol et al. 2008, 2009), while bifidobacteria in general have shown to have beneficial effects on health (see above). Most interestingly, the unaffected relatives of CD patients also have a different composition of their predominant microbiota compared with healthy individuals in general. The impact of these observations on IBD diagnostics and aetiology now has to be addressed.

The role of several different microorganisms in the aetiology of IBD has been studied in more detail. Adherentinvasive Escherichia coli (Darfeuille-Michaud 2002; Darfeuille-Michaud et al. 2004) and Mycobacterium avium subspecies paratuberculosis (Rosenfeld and Bressler 2010) are two prime suspects that have been implicated to be involved in $\mathrm{CD}$ pathogenesis. However, a causal relation has not yet been demonstrated. Recently, the presence of two species belonging to the family Enterobacteriaceae, Klebsiella pneumoniae and Proteus mirabilis, was correlated with the development of colitis in a mouse model (Garrett et al. 2010). The evidence that specific microorganisms can induce intestinal inflammation and cause IBD is, however, still inconclusive, despite the considerable amount of studies concerning this subject. In addition to the identification of potential pathogenic bacteria, other bacterial species have been suggested to protect against IBD. For example, it has been shown that the relative abundance of $F$. prausnitzii, a commensal bacterium with anti-inflammatory properties, is significantly decreased in CD patients compared with healthy individuals (Sokol et al. 2008).
High-throughput metagenomic studies can provide more insight in the composition and diversity of the intestinal microbiota of IBD patients. IBD is amongst the first diseases that have been the subject of metagenomic investigation (Qin et al. 2010). Based on the relative abundance of 155 microbial species (present in at least one individual at a genome coverage of $\geq 1 \%$ in this study population), it was possible to separate patients from healthy individuals, and UC from CD patients (Qin et al. 2010). The next step is to compare the IBD subpopulations with healthy individuals at microbial gene-level. On average, $25 \%$ fewer genes could be detected in the faecal samples of IBD patients compared with individuals not suffering from IBD (Qin et al. 2010). These results suggest that the microbiota of IBD patients has a lower functional diversity compared with healthy individuals. The intestinal microbiota in IBD patients produce reduced amounts of SCFA, in particular butyrate, while sulphate reduction (by sulphate-reducing bacteria) is increased (Fava and Danese 2011). In the near future, metagenomic studies like these will provide more insight in the shifts in functionality which characterises the differences between IBD patients and healthy individuals.

The observed compositional and functional changes in IBD patients suggest that the intestinal microbiota plays an important role in the aetiology and pathogenesis of IBD. However, up to this date it is still unclear whether dysbiosis is a direct cause for the inflammation in IBD, or merely the result of a disturbed environment in the GI tract. In the latter case, a role for the intestinal microbiota in disease 
maintenance and severity is possible and will have to be explored in the future.

\section{Microbial diversity and obesity}

Obesity is a complex disease characterised by excess body fat accumulation. It has been associated with phylum-level changes in the composition of the intestinal microbiota (Table 4). An increase in the relative abundance of Firmicutes and a reduction in the level of Bacteroidetes has been observed in both obese mice (ob/ob) (Ley et al. 2005) and humans (Ley et al. 2006). However, since the original publication, a series of studies have failed to confirm the study of Ley and colleagues and shown variable results with respect to the compositional changes in the microbiota of obese humans (Collado et al. 2008b; Duncan et al. 2008; Kalliomäki et al. 2008; Nadal et al. 2009; Santacruz et al. 2009, 2010; Schwiertz et al. 2010; Zhang et al. 2009). Altogether these data suggest that instead of phylum-level changes, more subtle changes in the composition of the intestinal microbiota are associated with the development of obesity. Recently, Turnbaugh and colleagues have observed a reduced compositional microbial diversity in obese individuals compared with lean individuals (Turnbaugh et al. 2009)

It is evident that (excessive) food intake has an influence on body (over)weight. Recently, a direct link between intestinal microbiota composition and body weight has been suggested. One of the first publications that provides evidence for this link is the publication by Bäckhed and colleagues for which they colonised germ-free mice with the microbiota of conventionally raised mice (Bäckhed et al. 2004). They observed an increase of body fat content of the colonised germ-free mice despite reduced food intake, which was suggested to be caused by the introduction of intestinal microbial communities. In a later study, it was demonstrated that the absence of intestinal microorganisms protected germ-free mice against the development of obesity after being fed a high-fat, sugarrich diet (Bäckhed et al. 2007). Furthermore, it was demonstrated that colonisation of germ-free mice with the microbiota of obese mice induced a significant greater increase in body fat weight compared with germ-free mice colonised with the microbiota of lean mice (Turnbaugh et al. 2006). In addition, these experiments in germ-free mice have demonstrated that the intestinal microbiota is involved in the regulation of fat storage. It was shown that introduction of an intestinal microbiota resulted in an increase in metabolic rate, modulation of de novo lipogenesis and an increase in the uptake of monosaccharides from the intestine (Bäckhed et al. 2004). Based on these results, it has been hypothesised that obese individuals are more efficient in converting food into usable energy and in storing this energy in fat than lean individuals (Turnbaugh et al. 2006). As discussed above, the intestinal microbiota has a crucial role in the digestion of food, in particular the metabolism of polysaccharides and oligosaccharides and the production of SCFA that provide the host with additional amounts of energy. Altered representation of bacterial genes and metabolic pathways, including those involved in nutrient harvest, were found to be related to obesity (Turnbaugh et al. 2009). The results from this study demonstrate that major insights in the differences between various physiological states of the host (in this case obese vs. lean) can be obtained by studying the functional microbial diversity in addition to phylogenetic diversity. In line with this conclusion is the observation that the amount of SCFA produced by the intestinal microbiota rather than the changes in the composition of the microbiota are important in the development of obesity (Schwiertz et al. 2010).

As for IBD and IBS, which were discussed above, also for obesity the question remains whether dysbiosis of the intestinal microbiota is a direct cause for obesity or whether it reflects a disturbed host environment. It needs to be established whether the changes in the intestinal microbial communities in obese individuals are not merely an adaptation to a change in the host's diet. Some of the studies that have shown an altered composition of the intestinal microbiota in obese individuals, have also incorporated analysis of the effect of diet change on the observed dysbiosis (Table 4) (Duncan et al. 2007, 2008; Ley et al. 2006; Nadal et al. 2009; Santacruz et al. 2009). Little is known, however, about the influence of dietary change on microbiota composition in humans. A recent study demonstrated rapid and reversible changes in the relative abundance of specific dominant bacterial groups after dietary changes (Walker et al. 2011a). Most striking was the strong increase in the relative abundance of Ruminococcus bromii and Eubacterium rectale phylotypes as result of a diet rich in resistant starch. It was suggested that indigestible dietary polysaccharides can substantially change the composition of the intestinal microbiota, however, it is likely that this depends on the initial composition of the intestinal microbiota. Interestingly, $R$. bromii and $E$. rectale were identified as key degraders of starch in an in vitro model of the human colon, using 16S rRNA-based stable isotope probing (Kovatcheva-Datchary et al. 2009). Recent studies in mice show that the influence of the diet (high-fat vs. standard chow or low-fat) on the composition of the intestinal microbiota is independent of genetic disposition for obesity (Hildebrandt et al. 2009; Murphy et al. 2010).

In addition to obesity, it has also been suggested that the intestinal microbiota is involved in obesity-associated metabolic disorders, such as type 2 diabetes metabolic endotoxemia, low-grade inflammation and adiposity (Cani 
Table 4 Overview of human studies that demonstrate an association between obesity and compositional dysbiosis of the intestinal microbiota determined with culture-independent methods

\begin{tabular}{|c|c|c|c|c|}
\hline $\begin{array}{l}\text { Study } \\
\text { material }\end{array}$ & Population & Analytical methods & Key findings & References \\
\hline $\begin{array}{l}\text { Faeces } \\
\text { (3 time points) }\end{array}$ & $\begin{array}{l}12 \text { Obese individuals (on diet) } \\
2 \text { Normal-weight individuals }\end{array}$ & $\begin{array}{l}\text { Clone library } \\
\text { sequencing }(16 \mathrm{~S})\end{array}$ & $\begin{array}{l}\text { Obese individuals compared with } \\
\quad \text { lean: } \\
\downarrow \text { Bacteriodetes } \\
\uparrow \text { Firmicutes }\end{array}$ & Ley et al. (2006) \\
\hline $\begin{array}{l}\text { Faeces } \\
\qquad(3 \text { time points) }\end{array}$ & 19 Obese individuals (on diet) & $\begin{array}{l}\text { FISH } \\
\text { GC }\end{array}$ & $\begin{array}{l}\text { Obese individuals on diet of } \\
\text { decreased carbohydrate intake: } \\
\downarrow \text { Roseburia } \\
\downarrow \text { Eubacterium rectale subgroup } \\
\text { of cluster XIVa } \\
\downarrow \text { bifidobacteria }\end{array}$ & $\begin{array}{l}\text { Duncan et al. } \\
(2007)^{*}\end{array}$ \\
\hline $\begin{array}{l}\text { Faeces } \\
\text { (2 time points) }\end{array}$ & $\begin{array}{l}18 \text { Obese pregnant women } \\
36 \text { Normal-weight pregnant } \\
\text { women }\end{array}$ & $\begin{array}{l}\text { FISH/flow cytometry } \\
\text { qPCR }\end{array}$ & $\begin{array}{l}\text { Overweighed pregnant women: } \\
\uparrow \text { Bacteroides } \\
\uparrow \text { Clostridium } \\
\uparrow \text { Staphylococcus }\end{array}$ & $\begin{array}{l}\text { Collado et al. } \\
(2008 \mathrm{~b})^{\#}\end{array}$ \\
\hline $\begin{array}{l}\text { Faeces } \\
\text { (3 time points) }\end{array}$ & $\begin{array}{l}23 \text { Overweight/obese } \\
\text { individuals (on diet) } \\
14 \text { Non-obese individuals }\end{array}$ & FISH & $\begin{array}{l}\text { During weight-loss diet: } \\
\leftrightarrow \text { Bacteriodetes } \\
\downarrow \text { butyrate-producing Firmicutes }\end{array}$ & $\begin{array}{l}\text { Duncan et al. } \\
(2008)^{*}\end{array}$ \\
\hline $\begin{array}{l}\text { Faeces } \\
\text { ( } 2 \text { time points) }\end{array}$ & $\begin{array}{l}25 \text { Overweight/obese children } \\
24 \text { Normal-weight children } \\
\text { (prospective study) }\end{array}$ & $\begin{array}{l}\text { FISH/flow cytometry } \\
\text { qPCR }\end{array}$ & $\begin{array}{l}\text { Intestinal microbiota during } \\
\text { infancy preceding overweight } \\
\text { during childhood: } \\
\downarrow \text { bifidobacteria } \\
\uparrow \text { Staphylococcus aureus }\end{array}$ & $\begin{array}{l}\text { Kalliomäki et al. } \\
\text { (2008) }\end{array}$ \\
\hline Faeces & $\begin{array}{l}20 \text { Obese individuals } \\
9 \text { Individuals with anorexia } \\
\text { nervosa } \\
20 \text { Normal-weight individuals }\end{array}$ & qPCR & $\begin{array}{l}\text { Obese individuals: } \\
\downarrow \text { Bacteriodetes } \\
\uparrow \text { Lactobacillus } \\
\text { Anorexic individuals: } \\
\uparrow \text { Methanobrevibacter smithii }\end{array}$ & $\begin{array}{l}\text { Armougom et al. } \\
\text { (2009) }\end{array}$ \\
\hline $\begin{array}{l}\text { Faeces } \\
\text { (2 time points) }\end{array}$ & $\begin{array}{l}39 \text { Overweight/obese } \\
\text { adolescents (on diet and } \\
\text { physical activity) }\end{array}$ & FISH/flow cytometry & $\begin{array}{l}\text { Obese individuals: } \\
\uparrow C \text {. histolyticum } \\
\uparrow E \text {. rectale-C. coccoides } \\
\text { Upon calorie restricted diet: } \\
\downarrow C . \text { histolyticum } \\
\downarrow \text { C. lituseburense } \\
\downarrow \text { E. rectale-C. coccoides } \\
\uparrow \text { Bacteroides-Prevotella group }\end{array}$ & Nadal et al. $(2009)^{\dagger}$ \\
\hline $\begin{array}{l}\text { Faeces } \\
\qquad(2 \text { time points) }\end{array}$ & $\begin{array}{l}36 \text { Overweight/obese } \\
\text { adolescents (on diet and } \\
\text { physical activity) }\end{array}$ & qPCR & $\begin{array}{l}\text { Obese adolescents on diet with a } \\
\text { high weight-loss: } \\
\uparrow \text { Total bacteria } \\
\uparrow B \text {. fragilis group } \\
\uparrow C \text {. leptum group } \\
\uparrow \text { B. catenulatum group } \\
\downarrow \text { C. coccoides group } \\
\downarrow \text { Lactobacillus } \text { group }\end{array}$ & $\begin{array}{l}\text { Santacruz et al. } \\
(2009)^{\dagger}\end{array}$ \\
\hline
\end{tabular}


Table 4 continued

\begin{tabular}{|c|c|c|c|c|}
\hline $\begin{array}{l}\text { Study } \\
\text { material }\end{array}$ & Population & Analytical methods & Key findings & References \\
\hline $\begin{array}{l}\text { Faeces } \\
\qquad(2 \text { time points) }\end{array}$ & $\begin{array}{l}31 \text { Monozygotic twin pairs } \\
23 \text { Dizygotic twin pairs } \\
46 \text { Mothers of twin pairs }\end{array}$ & $\begin{array}{l}\text { Sanger sequencing } \\
\text { (16S) } \\
454 \text { FLX titanium } \\
\text { sequencing } \\
\text { (metagenome) }\end{array}$ & $\begin{array}{l}\text { Most obesity-associated genes are } \\
\text { from: } \\
\text { Actinobacteria } \\
\text { Firmicutes } \\
\text { Most lean-enriched genes are from } \\
\text { Bacteroidetes }\end{array}$ & $\begin{array}{l}\text { Turnbaugh et al. } \\
\text { (2009) }\end{array}$ \\
\hline Faeces & $\begin{array}{l}3 \text { Obese individuals } \\
3 \text { Individuals with a gastric- } \\
\text { bypass } \\
3 \text { Normal-weight individuals }\end{array}$ & $\begin{array}{l}\text { Clone library } \\
\text { sequencing (16S) } \\
454 \text { FLX titanium } \\
\text { sequencing }(16 S) \\
\text { qPCR }\end{array}$ & $\begin{array}{l}\text { Obese individuals: } \\
\uparrow \mathrm{H}_{2} \text {-producing Prevotellaceae } \\
\uparrow \mathrm{H}_{2} \text {-utilizing methanogenic } \\
\text { Archaea }\end{array}$ & Zhang et al. (2009) \\
\hline Faeces & $\begin{array}{l}15 \text { Obese Indian adolescents } \\
13 \text { Non-obese Indian } \\
\text { adolescents }\end{array}$ & qPCR & $\begin{array}{l}\text { Obese children: } \\
\leftrightarrow \text { Bacteroides-Prevotella } \\
\leftrightarrow \text { Bifidobacterium } \\
\leftrightarrow \text { L. acidophilus } \\
\leftrightarrow \text { E. rectale } \\
\uparrow F \text {. prausnitzii }\end{array}$ & $\begin{array}{l}\text { Balamurugan et al. } \\
\text { (2010) }\end{array}$ \\
\hline $\begin{array}{l}\text { Faeces } \\
\text { (2 time points) }\end{array}$ & $\begin{array}{l}16 \text { Infants of overweight } \\
\text { women } \\
26 \text { Infants of normal-weight } \\
\text { women }\end{array}$ & $\begin{array}{l}\text { FISH/flow cytometry } \\
\text { qPCR }\end{array}$ & $\begin{array}{l}\text { Infants of overweight mothers: } \\
\uparrow \text { Bacteroides } \\
\uparrow \text { Staphylococcus }\end{array}$ & $\begin{array}{l}\text { Collado et al. } \\
(2010)^{\#}\end{array}$ \\
\hline Faeces & $\begin{array}{l}33 \text { Obese individuals } \\
35 \text { Overweight individuals } \\
30 \text { Normal-weight individuals }\end{array}$ & $\begin{array}{l}\text { qPCR } \\
\text { GC }\end{array}$ & $\begin{array}{l}\text { Obese individuals compared with } \\
\text { lean: } \\
\uparrow \text { Bacteriodetes } \\
\downarrow \text { Firmicutes }\end{array}$ & $\begin{array}{l}\text { Schwiertz et al. } \\
\text { (2010) }\end{array}$ \\
\hline Faeces & $\begin{array}{l}16 \text { Overweight pregnant } \\
\text { women } \\
34 \text { Normal-weight pregnant } \\
\text { women }\end{array}$ & qPCR & $\begin{array}{l}\text { Overweight pregnant women: } \\
\downarrow \text { Bifidobacterium } \\
\downarrow \text { Bacteroides } \\
\uparrow \text { Staphylococcus } \\
\uparrow \text { Enterobacteriaceae } \\
\uparrow \text { E. coli }\end{array}$ & $\begin{array}{l}\text { Santacruz et al. } \\
\text { (2010) }\end{array}$ \\
\hline
\end{tabular}

All studies have used the body mass index (BMI) to define normal weight, overweight and obesity. Studies that have used subjects from the same cohort are indicated by $*,{ }^{*}$ and ${ }^{\dagger}$

FISH fluorescence in situ hybridisation, $G C$ gas chromatography, $q P C R$ quantitative polymerase chain reaction

and Delzenne 2009; Ley 2010; Vrieze et al. 2010). In a recent study, a high-throughput sequencing approach was used to demonstrate that type 2 diabetes, a metabolic disease primarily caused by obesity-linked insulin resistance, is associated with changes in the composition of the intestinal microbiota (Larsen et al. 2010). The relative abundance of Firmicutes was significantly lower in diabetic patients compared with non-diabetic persons. On the other hand, the Bacteroidetes and Proteobacteria were present in higher abundance. In addition, the Bacteroidetes/ Firmicutes and Bacteroides-Prevotella/C.coccoides-E.rectale ratios were positively and significantly correlated with plasma glucose levels.
Microbial diversity and other human diseases

In addition to IBD, IBS and obesity, the intestinal microbiota has also been suggested to be involved in several other (chronic) diseases and disorders. Associations have been described between intestinal microbial dysbiosis and intestinal diseases such as coeliac disease, colorectal cancer, pouchitis and necrotizing enterocolitis (NEC) (Table 5). The most recent data show that the intestinal microbiota of coeliac disease patients displays a greater diversity than healthy controls with higher numbers of Bacteroides-Prevotella (De Palma et al. 2010; Schippa et al. 2010). Bifidobacterium, Clostridium histolyticum, $C$. 
Table 5 Overview of human studies that demonstrate an association between intestinal disease and compositional dysbiosis of the intestinal microbiota

\begin{tabular}{|c|c|c|c|}
\hline Study material & Population & Analytical methods & Reference \\
\hline \multicolumn{4}{|l|}{ Coeliac disease } \\
\hline Faeces & $\begin{array}{l}26 \text { Coeliac patients (no diet, active disease) } \\
23 \text { Children without gluten intolerance }\end{array}$ & $\begin{array}{l}\text { Conventional culturing } \\
\text { FISH }\end{array}$ & Collado et al. (2007) \\
\hline Duodenal biopsies & $\begin{array}{l}20 \text { Coeliac patients (no diet, active disease) } \\
10 \text { Coeliac patients (gluten-free diet, } \\
\text { symptom-free) } \\
8 \text { Children without gluten intolerance }\end{array}$ & FISH/flow cytometry & Nadal et al. (2007) \\
\hline Faeces & $\begin{array}{l}10 \text { Coeliac patients (no diet, active disease) } \\
10 \text { Children without gluten intolerance }\end{array}$ & DGGE & Sanz et al. (2007) \\
\hline $\begin{array}{l}\text { Duodenal biopsies } \\
\text { faeces }\end{array}$ & $\begin{array}{l}30 \text { Coeliac patients (no diet) } \\
18 \text { Coeliac patients (gluten-free diet) } \\
30 \text { Children without gluten intolerance }\end{array}$ & qPCR & Collado et al. (2008a) \\
\hline Faeces & $\begin{array}{l}24 \text { Coeliac patients (no diet, active disease) } \\
18 \text { Coeliac patients (gluten-free diet, } \\
\text { symptom-free) } \\
20 \text { Children without gluten intolerance }\end{array}$ & FISH/flow cytometry & De Palma et al. (2010) \\
\hline Duodenal biopsies & $\begin{array}{l}20 \text { Coeliac patients (active disease/ } \\
\text { symptom-free) } \\
10 \text { Children without gluten intolerance }\end{array}$ & TGGE & Schippa et al. (2010) \\
\hline \multicolumn{4}{|l|}{ Colorectal cancer } \\
\hline Faeces & $\begin{array}{l}18 \text { Patients with polyps } \\
32 \text { Individuals with high -risk for colon cancer } \\
38 \text { Individuals with low-risk for colon cancer }\end{array}$ & Conventional culturing & Moore and Moore (1995) \\
\hline Faeces & $\begin{array}{l}13 \text { Patients at high risk for sigmoid colon cancer } \\
14 \text { Healthy individuals }\end{array}$ & Conventional culturing & Kanazawa et al. (1996) \\
\hline Faeces (3 time points) & $\begin{array}{l}20 \text { Colon cancer patients } \\
20 \text { Polypectomized patients } \\
20 \text { Healthy individuals }\end{array}$ & DGGE & Scanlan et al. (2008) \\
\hline Colorectal biopsies & $\begin{array}{l}21 \text { Individuals with adenomas } \\
23 \text { Individuals without adenomas }\end{array}$ & $\begin{array}{l}\text { T-RFLP } \\
\text { Clone library sequencing }(16 S) \\
\text { FISH }\end{array}$ & Shen et al. (2010) \\
\hline \multicolumn{4}{|l|}{ Pouchitis } \\
\hline $\begin{array}{l}\text { Pouch biopsies } \\
\text { Ileostomy effluent } \\
\text { Faeces }\end{array}$ & $\begin{array}{l}12 \text { Patients with pouchitis } \\
14 \text { Patients with indeterminable pouchitis } \\
23 \text { Patients without pouchitis } \\
20 \text { Ileostomy patients } \\
9 \text { Healthy individuals }\end{array}$ & Conventional culturing & Onderdonk et al. (1992) \\
\hline Pouch effluent & $\begin{array}{l}5 \text { Patients with pouchitis } \\
9 \text { Patients without pouchitis }\end{array}$ & Conventional culturing & $\begin{array}{l}\text { Ruseler-van Embden et al. } \\
\text { (1994) }\end{array}$ \\
\hline Pouch effluent & $\begin{array}{l}\text { UC patients: } \\
8 \text { Patients with healthy pouches } \\
9 \text { Patients, no active pouchitis for at least } 1 \text { year } \\
9 \text { Patients, no active pouchitis for at least } 6 \text { weeks } \\
11 \text { Patients with pouchitis, on antibiotic treatment } \\
8 \text { Patients with pouchitis } \\
\text { FAP patients: } \\
5 \text { Patients with healthy pouches }\end{array}$ & Conventional culturing & Ohge et al. (2005) \\
\hline
\end{tabular}


Table 5 continued

\begin{tabular}{|c|c|c|c|}
\hline Study material & Population & Analytical methods & Reference \\
\hline Pouch effluent & $\begin{array}{l}9 \text { Patients with pouchitis (UC) } \\
13 \text { Patients with healthy pouches (UC) }\end{array}$ & Conventional culturing & Iwaya et al. (2006) \\
\hline Ileum biopsies & 5 Patients with pouchitis (UC) & LH-PCR & Komanduri et al. (2007) \\
\hline Pouch biopsies & 15 Patients with healthy pouches (UC) & Clone library sequencing (16S) & \\
\hline Pouch effluent & 13 Healthy individuals & & \\
\hline Pouch effluent & $\begin{array}{l}5 \text { Patients with pouchitis (UC) } \\
15 \text { Patients with healthy pouches (UC) }\end{array}$ & $\begin{array}{l}\text { T-RFLP } \\
\text { Clone library sequencing (16S) }\end{array}$ & Lim et al. (2009) \\
\hline Pouch contents & 9 Patients with pouchitis (UC) & T-RFLP & Zella et al. (2011) \\
\hline Pouch biopsies & $\begin{array}{l}3 \text { Patients with healthy pouches (UC) } \\
7 \text { Patients with healthy pouches (FAP) }\end{array}$ & Clone library sequencing $(16 S)$ & \\
\hline \multicolumn{4}{|c|}{ Necrotizing enterocolitis } \\
\hline Faeces & $\begin{array}{l}10 \text { Preterm infants with NEC } \\
10 \text { Preterm infants without NEC }\end{array}$ & $\begin{array}{l}\text { T-RFLP } \\
\text { Clone library sequencing (16S) }\end{array}$ & Wang et al. (2009) \\
\hline $\begin{array}{l}\text { Faeces (several time } \\
\text { points) }\end{array}$ & $\begin{array}{l}6 \text { Preterm infants with NEC or suspected sepsis } \\
6 \text { Preterm control infants }\end{array}$ & $\begin{array}{l}\text { DGGE } \\
\text { 454 FLX titanium sequencing } \\
(16 \mathrm{~S})\end{array}$ & Mshvildadze et al. (2010) \\
\hline
\end{tabular}

The intestinal diseases IBD, IBS and obesity are discussed separately in the article

$D G G E$ denaturing gradient gel electrophoresis, FAP familial anastomosis polyposis, FISH fluorescence in situ hybridisation, $L H-P C R$ length heterogeneity polymerase chain reaction, $q P C R$ quantitative polymerase chain reaction, T-RFLP terminal-restriction fragment length polymorphism, $T G G E$ temperature gradient gel electrophoresis, $U C$ ulcerative colitis

lituseburense and $F$. prausnitzii were less abundant in coeliac disease patients (De Palma et al. 2010). Also in the case of colorectal cancer, the bacterial diversity and richness was observed to be higher in patients compared with healthy controls (Shen et al. 2010). In addition, the intestinal microbiota composition of colorectal cancer patients differs from that of healthy controls, however, no consistent pattern has yet been observed.

The mucosal and faecal microbiota of UC pouchitis patients contained more Clostridium and Eubacterium and fewer Lactobacillus and Streptococcus genera compared with the microbiota of healthy pouches from familial adenomatous polyposis (FAP) patients (Lim et al. 2009; Zella et al. 2011). Luminal samples of UC pouchitis patients contained more Firmicutes and Verrucomicrobia and fewer Bacteroidetes and Proteobacteria compared with FAP patients.

The overall microbiota profiles of premature infants with necrotizing enterocolitis (NEC) were not distinguishable from that of control subjects, but 16S rRNA gene sequence analysis detected Citrobacter-like sequences and an increased frequency of Enterococcus-like sequences (Mshvildadze et al. 2010).

Intestinal microbial dysbiosis has also been observed in extra-intestinal diseases such as atopic and allergic diseases, autism, type 2 diabetes and rheumatoid arthritis (Table 6). In children who develop an allergic disease later in life, a reduced diversity of faecal microbiota was already observed at 1 week of age (Wang et al. 2009; Niers et al., personal communication). During the first 2 months of life, they were less often colonised with lactobacilli group I (L. rhamnosus, L. casei, L. paracasei), B. adolescentis and Clostridium difficile (Kalliomäki et al. 2001; Sjögren et al. 2009).

The number of Clostridium species found in the stools of children with autism was greater than in the stools of control children, specifically of the $C$. histolyticum group (Clostridium clusters I and II) (Finegold et al. 2002; Parracho et al. 2005). Bacteroidetes was found at high levels in the severely autistic children while populations of the Bifidobacterium genus were reduced (Finegold et al. 2010).

Firmicutes and Clostridia are reduced in type 2 diabetes (Larsen et al. 2010). Furthermore, the Bacteroidetes/Firmicutes ratio as well as Bacteroides-Prevotella/C. coccoides- $E$. rectale ratio were observed to be correlated with plasma glucose concentration. In a Chinese population of diabetes patients, reduced populations of bifidobacteria were found ( $\mathrm{Wu}$ et al. 2010).

In comparison to patients with fibromyalgia, patients with rheumatoid arthritis had significantly less bifidobacteria and bacteria of the Bacteroides-Prevotella group, Bacteroides fragilis subgroup, and E. rectale-C. coccoides group (Vaahtovuo et al. 2008).

Almost all of the diseases and disorders mentioned above are largely undefined and have a heterogeneous aetiology, which makes it difficult to relate changes in 
Table 6 Overview of human studies that demonstrate an association between extra-intestinal disease and compositional dysbiosis of the intestinal microbiota

\begin{tabular}{|c|c|c|c|}
\hline Study material & Population & Analytical methods & References \\
\hline \multicolumn{4}{|c|}{ Atopic and allergic diseases } \\
\hline Faeces & $\begin{array}{l}27 \text { Allergic children } \\
36 \text { Non-allergic children }\end{array}$ & Conventional culturing & Björkstén et al. (1999) \\
\hline $\begin{array}{l}\text { Faeces } \\
\text { (5 time points) }\end{array}$ & $\begin{array}{l}18 \text { Infants who developed allergy } \\
26 \text { Infants who remained non-allergic }\end{array}$ & Conventional culturing & Björkstén et al. (2001) \\
\hline $\begin{array}{l}\text { Faeces } \\
\text { (2 time points) }\end{array}$ & 76 Infants at high risk for atopic disease & $\begin{array}{l}\text { Conventional culturing } \\
\text { FISH }\end{array}$ & Kalliomäki et al. (2001) \\
\hline $\begin{array}{l}\text { Faeces } \\
\text { (2/3 time points) }\end{array}$ & $\begin{array}{l}27 \text { Infants with atopic dermatitis } \\
10 \text { Infants without atopic dermatitis }\end{array}$ & $\begin{array}{l}\text { Conventional culturing } \\
\text { FISH }\end{array}$ & Kirjavainen et al. (2001) \\
\hline Faeces & $\begin{array}{l}30 \text { Children with atopic dermatitis } \\
68 \text { Children without atopic dermatitis }\end{array}$ & Conventional culturing & Watanabe et al. (2003) \\
\hline Faeces & 957 Infants & qPCR & Penders et al. (2007) \\
\hline Faeces & $\begin{array}{l}20 \text { Allergic children } \\
20 \text { Non-allergic children }\end{array}$ & DGGE & Štšepetova et al. (2007) \\
\hline $\begin{array}{l}\text { Faeces } \\
\text { (3 time points) }\end{array}$ & $\begin{array}{l}10 \text { Allergic infants } \\
16 \text { Non-allergic infants }\end{array}$ & qPCR & Suzuki et al. (2007) \\
\hline Faeces & $\begin{array}{l}37 \text { Infants with atopic dermatitis } \\
24 \text { Infants without atopic dermatitis }\end{array}$ & $\begin{array}{l}\text { TGGE } \\
\text { FISH/flow cytometry }\end{array}$ & Gore et al. (2008) \\
\hline Faeces & $\begin{array}{l}15 \text { Infants who developed atopic dermatitis } \\
20 \text { Infants who remained without atopic dermatitis }\end{array}$ & $\begin{array}{l}\text { T-RFLP } \\
\text { TGGE }\end{array}$ & Wang et al. (2008) \\
\hline $\begin{array}{l}\text { Faeces } \\
\text { (3 time points) }\end{array}$ & $\begin{array}{l}16 \text { Infants who developed allergy } \\
31 \text { Infants who remained non-allergic }\end{array}$ & qPCR & Sjögren et al. (2009) \\
\hline \multicolumn{4}{|l|}{ Autism } \\
\hline $\begin{array}{l}\text { Faeces } \\
\text { Stomach contents }\end{array}$ & $\begin{array}{l}13 \text { Autistic children } \\
8 \text { Non-autistic children }\end{array}$ & $\begin{array}{l}\text { Conventional culturing } \\
16 \mathrm{~S} \text { rRNA gene sequencing }\end{array}$ & Finegold et al. (2002) \\
\hline \multicolumn{4}{|c|}{ Small intestine contents } \\
\hline Faeces & $\begin{array}{l}15 \text { Autistic children } \\
8 \text { Non-autistic children }\end{array}$ & qPCR & Song et al. (2004) \\
\hline Faeces & $\begin{array}{l}58 \text { Autistic children } \\
12 \text { Non-autistic siblings } \\
10 \text { Non-autistic children }\end{array}$ & FISH & Parracho et al. (2005) \\
\hline Faeces & $\begin{array}{l}33 \text { Autistic children } \\
7 \text { Non-autistic siblings } \\
8 \text { Non-autistic children }\end{array}$ & 454 FLX titanium sequencing $(16 S)$ & Finegold et al. (2010) \\
\hline \multicolumn{4}{|l|}{ Diabetes type 2} \\
\hline Faeces & $\begin{array}{l}16 \text { Type } 2 \text { diabetic patients } \\
12 \text { Non-diabetic individuals }\end{array}$ & $\begin{array}{l}\text { DGGE } \\
\text { qPCR }\end{array}$ & Wu et al. (2010) \\
\hline Faeces & $\begin{array}{l}18 \text { Type } 2 \text { diabetic patients } \\
18 \text { Non-diabetic individuals }\end{array}$ & $\begin{array}{l}\text { qPCR } \\
454 \text { FLX titanium sequencing }(16 S)\end{array}$ & Larsen et al. (2010) \\
\hline Rheumatoid arthriti & & & \\
\hline Faeces & $\begin{array}{l}51 \text { Patients with early rheumatoid arthritis } \\
50 \text { Patients with fibromyalgia }\end{array}$ & FISH/flow cytometry & Vaahtovuo et al. (2008) \\
\hline
\end{tabular}

$\overline{D G G E \text { denaturing gradient gel electrophoresis, FISH fluorescence in situ hybridisation, } q P C R \text { quantitative polymerase chain reaction, } T \text { - } R F L P}$ terminal-restriction fragment length polymorphism, $T G G E$ temperature gradient gel electrophoresis

microbiota composition and diversity to disease. Again, also for all these diseases the causality argument of the observed microbiota changes is unresolved. Ultimately, causality and knowledge of the underlying mechanisms will be crucial for a full understanding of the role of the intestinal microbiota in the aetiology of specific diseases. 


\section{Modulation of the intestinal microbiota}

Since it is known that the intestinal microbiota plays an important role in human health and disease, manipulation of these microorganisms by antibiotics, probiotics, prebiotics and synbiotics are attractive approaches to improve and maintain health (Gareau et al. 2010; Preidis and Versalovic 2009).

Antibiotics are widely used as antimicrobial agents to treat bacterial infections caused by pathogenic microorganisms. In general, however, antibiotics (even narrowspectrum antibiotics) do not only affect pathogens, but also commensal intestinal microbial communities. This can result in dysbiosis of the intestinal microbiota, subsequently leading to intestinal problems, such as antibioticassociated diarrhoea (AAD) (McFarland 1998). The antibiotic-induced disturbances in microbiota composition can be temporary, returning to its original composition within 2 months, but recently also medium and long-term disturbances in (specific) microbial communities have been described (Dethlefsen et al. 2008; Jernberg et al. 2007, 2010; Koning et al. 2010). An additional problem of the widespread antibiotic use, is the increased prevalence of antibiotic resistance resulting from the transfer of antibiotic resistance genes amongst microorganisms (Jernberg et al. 2010)

The intestinal microbiota can be modulated in a more biological manner by the use of probiotics. According to the definition formulated by the World Health Organisation (WHO) probiotics are 'live microorganisms which, when administered in adequate amounts, confer a health benefit on the host' (FAO/WHO 2002). Moreover, prebiotics are used to manipulate the microbiota composition in the GI tract. The definition of prebiotics is even more generic than the one of probiotics: "non-digestible food ingredients that, when consumed in sufficient amounts, selectively stimulate the growth and/or activity(ies) of one or a limited number of microbial genus(era)/species in the gut microbiota that confer(s) health benefits to the host' (Roberfroid et al. 2010). Mixtures of both probiotics and prebiotics are referred to as synbiotics.

The final part of this review will focus on probiotics as a way to modulate the intestinal microbiota. The opportunities for probiotic intervention in maintaining and restoring health are increasingly being acknowledged, and the field of probiotic research has grown significantly during the past few years (Gareau et al. 2010; Ng et al. 2009; Rijkers et al. 2010).

An introduction to probiotics

In line with the very generic definition of probiotics, many different microorganisms have been studied for their potential use as a probiotic, in relation with a wide range of biological or clinical effects. Most of the microorganisms that have been studied are naturally present in the human GI tract. At this moment, the most commonly used probiotic microorganisms belong mainly to the bacterial genera Lactobacillus and Bifidobacterium (Boesten and De Vos 2008; Kleerebezem and Vaughan 2009). These two genera contain a large number of species and strains of which many are being used as probiotic strains. In addition to these genera, the probiotic market contains members from some additional lactic acid bacterial genera, such as Streptococcus and Enterococcus, and members from the genera Bacillus and Propionibacterium. Furthermore, some gram-negative bacteria (e.g. E. coli Nissle 1917) and yeast (e.g. Saccharomyces) are being used as probiotic microorganisms (Gareau et al. 2010; Holzapfel et al. 1998; Iannitti and Palmieri 2010).

Numerous health-beneficial effects have been attributed to probiotic microorganisms (Iannitti and Palmieri 2010; $\mathrm{Ng}$ et al. 2009). In general, these health benefits can be categorised into three levels of probiotic action (Rijkers et al. 2010). First of all, probiotic microorganisms can act directly within the GI tract (level 1), for example by direct interaction with the intestinal microbiota or by enzymatic activities. Secondly, they can interact directly with the intestinal mucus layer and epithelium (level 2), thereby influencing the intestinal barrier function and the mucosal immune system. Thirdly, probiotics can have effects outside the GI tract (level 3), for example on the systemic immune system and other organs, such as the liver and the brain. Although in vivo data are emerging, most of the mechanistic studies with probiotic microorganisms have been performed in vitro, ex vivo or with the aid of animal models. The in vitro activity of a given probiotic does not necessarily correlate with the efficacy of the intended clinical in vivo. In addition, it is important to note that each probiotic strain has its own specific properties. The health benefits that can be attributed to one probiotic strain cannot be extrapolated to other probiotic strains or mixtures of strains. Even closely related microbial strains of the same species may have different physiological effects (Medina et al. 2007; Meijerink et al. 2010; López et al. 2010; Snel et al. 2010; Van Hemert et al. 2010; Vissers et al. 2010, 2011).

Nowadays, multistrain or multispecies probiotic mixtures, which contain more than one probiotic strain, are becoming increasingly popular (Chapman et al. 2011; Timmerman et al. 2004). Compared with single strain probiotics, probiotic mixtures have the possible advantage that the properties of single strains may have additive or even synergistic effects when put in a mixture together with other probiotics strains, which can result in higher efficacy. Another potential advantage of probiotic mixtures 
may be that compared with a single strain probiotic a wider range of health benefits could be accomplished. In contrast, mixing of probiotic strains might also result in reduced efficacy since individual strains may have opposite effects or even inhibit each other. There are, however, a limited number of in vivo studies available that compare the effects of a probiotic mixture with those of the individual strains (Chapman et al. 2011). This means that the evidence for the hypothesis that probiotic mixtures are more effective than the individual strains is still limited.

The influence of probiotics on the composition and diversity of the intestinal microbiota

Modulation of the intestinal microbiota (part of level 1 probiotic action) is one of the potential health-beneficial effects of probiotics. The mechanisms by which probiotic microorganisms are able to modify the intestinal microbiota include reduction of luminal $\mathrm{pH}$, competition for nutrients, secretion of anti-microbial compounds (bacteriocins), prevention of bacterial adhesion and evasion of epithelial cells, and induction of the production of antimicrobial compounds (defensins) by the host (Fooks and Gibson 2002; Ng et al. 2009). By these mechanisms, probiotics can not only potentially modulate the intestinal microbiota composition, but also prevent pathogenic bacterial overgrowth.

Up to this date, many studies have been performed that examine the effects of probiotics on the composition and diversity of the intestinal microbiota, both in diseased and healthy individuals. For a given disease, the desired outcome of probiotic intervention is the modulation of the intestinal microbiota in such a way that a healthy microbiota composition is achieved. However, also other parameters have been addressed such as stabilisation of the microbiota as in the case of IBS and a multispecies probiotic, determined with the use of a phylogenetic microarray (Kajander et al. 2008). The interpretation of the effects of probiotics on the intestinal microbiota composition in healthy individuals are, however, more difficult to interpret (Table 7). Those studies do provide information on the effects of probiotics on the intestinal microbiota without a potential bias caused by disease effects. However, this does not imply that in a diseased situation these probiotic products will have the same influence on the intestinal microbiota.

Until recently, in most of the probiotic studies conventional culture-based methods have been used to study the influence of probiotics on the intestinal microbiota. However, since a few years culture-independent methods are now also being applied in probiotic research (Table 7). In general, demonstrating the colonisation of the supplemented probiotic microorganism(s) has been the primary aim of most studies in healthy individuals. In most cases, a transient colonisation of the probiotic microorganism(s) has been observed. It is still questionable, however, whether probiotic strains would need to colonise in order to be effective or whether transient presence would also suffice to exert health-beneficial effects.

The probiotic studies performed in humans have almost exclusively examined the effect of probiotic administration on the composition of the faecal microbiota, whereas other niches of the GI tract have hardly been studied thus far (Table 7). As already indicated, even major local changes in microbiota composition in specific niches of the GI tract might not be reflected in the faeces. This means that there is still a major gap in knowledge on the influence of probiotic microorganisms on the intestinal microbiota. In addition, the influence of probiotic microorganisms on mucosa-associated intestinal microbiota is also not well studied. However, these interactions are possibly of key importance in relation to disease pathogenesis, since mucosa-associated microorganisms are in more close contact with the intestinal barrier and immune system. One of the few examples of a study on the in vivo effects of probiotics on the human host is a recent study by Van Baarlen et al. (2009). The authors examined the influence of a probiotic microorganism on human duodenal mucosal gene expression and they showed that changes in gene expression patterns, especially in the NF- $\kappa \beta$ dependent pathways, induced by Lactobacillus plantarum WCFS1 could be linked to the establishment of immunotolerance in human adults.

In contrast with most human probiotic studies, animal studies have focused on the spatial influence of probiotics on the intestinal microbiota (Table 7). However, to which extent these results reflect the human situation has to be determined. Administration of a given probiotic strain will result in the (temporarily) increase of that strain the GI tract, but may also change the overall composition of the intestinal microbiota. Indeed, the results of relevant experiments performed thus far demonstrate that probioticinduced changes in microbiota composition are not restricted to the administered species. Which probiotic microorganisms are able to influence the relative abundance of which specific intestinal microorganisms are questions that are currently under study. It should be realised, however, that a change in composition or diversity of the intestinal microbiota by probiotic intervention is not a health benefit by itself.

As discussed previously, dysbiosis of the intestinal microbiota has been associated with a growing number of (intestinal) diseases. Since modulation of the composition of intestinal microbiota by probiotics was demonstrated to be possible, probiotic intervention has the potential to counterbalance intestinal dysbiosis and thus restore health. 
Table 7 Details of studies performed to examine the effects of probiotic intervention on intestinal microbiota composition of healthy subjects determined with culture-independent methods

\begin{tabular}{|c|c|c|c|c|c|}
\hline Population & $\begin{array}{l}\text { Study groups } \\
\text { (based on treatment) }\end{array}$ & $\begin{array}{l}\text { Study } \\
\text { material }\end{array}$ & $\begin{array}{l}\text { Analytical } \\
\text { methods }\end{array}$ & Key findings & References \\
\hline \multicolumn{6}{|l|}{ Animals } \\
\hline $\begin{array}{l}\text { Healthy rats } \\
\quad(n=30)\end{array}$ & $\begin{array}{l}\text { Probiotic: B. lactis } \mathrm{B} 1 \text { and } \\
\text { S. thermophilus } \\
\text { Prebiotic: FOS } \\
\text { Placebo: only carrier } \\
\text { material }\end{array}$ & $\begin{array}{r}\text { Caecum (tissue } \\
\text { and contents) }\end{array}$ & $\begin{array}{l}\text { Conventional } \\
\text { culturing } \\
\text { DGGE }\end{array}$ & $\begin{array}{l}\text { Both prebiotic and probiotic } \\
\text { group: } \\
\downarrow \text { Clostridia } \\
\downarrow \text { Bacteroides } \\
\downarrow \text { total anaerobes } \\
\text { Prebiotic-treated group: } \\
\downarrow \text { coliforms } \\
\uparrow \text { Bifidobacterium } \\
\text { Probiotic-treated group: } \\
\uparrow \text { diversity } \\
\uparrow \text { coliforms }\end{array}$ & $\begin{array}{l}\text { Montesi et al. } \\
\text { (2005) }\end{array}$ \\
\hline $\begin{array}{l}\text { Healthy mice } \\
\quad(n=16)\end{array}$ & $\begin{array}{l}\text { Probiotic: } L . \text { casei } \\
\text { Probiotic: } L \text {. plantarum } \\
\text { Probiotic: mixture of } L . \\
\text { casei and } L \text {. plantarum } \\
\text { Control: no treatment }\end{array}$ & $\begin{array}{l}\text { Faeces } \\
\text { Intestinal tissue }\end{array}$ & $\begin{array}{l}\text { DGGE } \\
\text { T-RFLP } \\
\text { Clone-library } \\
\text { sequencing }\end{array}$ & $\begin{array}{l}\text { Mixture-treated group: } \\
\text { No significant effect on } \\
\text { dominant microbiota } \\
\text { composition } \\
\text { Shifts in the diversity of } \\
\text { Lactobacillus species }\end{array}$ & $\begin{array}{l}\text { Fuentes et al. } \\
\text { (2008) }\end{array}$ \\
\hline $\begin{array}{l}\text { Healthy fish (red } \\
\text { tilapia) }(n=12)\end{array}$ & $\begin{array}{l}\text { Probiotic: diet containing } \\
\text { Pediococcus acidilactici } \\
\text { Placebo: normal diet }\end{array}$ & $\begin{array}{l}\text { Intestinal } \\
\text { contents }\end{array}$ & $\begin{array}{l}\text { Conventional } \\
\text { culturing } \\
\text { DGGE }\end{array}$ & $\begin{array}{l}\text { Probiotic-treated group: } \\
\downarrow \text { Species richness and diversity } \\
\text { Transiently colonization } \\
\text { by } P \text {. acidilactici }\end{array}$ & $\begin{array}{l}\text { Ferguson et al. } \\
\text { (2010) }\end{array}$ \\
\hline \multicolumn{6}{|l|}{ Humans } \\
\hline $\begin{array}{l}\text { Healthy adults } \\
\quad(n=10)\end{array}$ & $\begin{array}{l}\text { Probiotic: milk powder } \\
\text { containing L. rhamnosus } \\
\text { DR20 }\end{array}$ & Faeces & $\begin{array}{l}\text { Conventional } \\
\text { culturing } \\
\text { FISH } \\
\text { DGGE }\end{array}$ & $\begin{array}{l}\text { Probiotic-treated group: } \\
\text { No significant effect on } \\
\text { dominant microbiota } \\
\text { composition }\end{array}$ & $\begin{array}{l}\text { Tannock et al. } \\
(2000)\end{array}$ \\
\hline $\begin{array}{l}\text { Healthy adults } \\
\quad(n=30)\end{array}$ & $\begin{array}{l}\text { Probiotic: B. animalis } \\
\text { subsp. lactis } \mathrm{Bb}-12 \\
\text { Prebiotic: GOS } \\
\text { Synbiotic: GOS and } \\
\text { B. animalis subsp. lactis } \\
\text { Bb-12 }\end{array}$ & Faeces & DGGE & $\begin{array}{l}\text { All groups: } \\
\text { No qualitative changes in faecal } \\
\text { Bifidobacterium communities } \\
\text { Probiotic/synbiotic-treated } \\
\text { groups: } \\
\text { Transiently colonization by } \\
\text { B. animalis subsp. lactis } \mathrm{Bb}-12\end{array}$ & $\begin{array}{l}\text { Satokari et al. } \\
\text { (2001) }\end{array}$ \\
\hline $\begin{array}{l}\text { Healthy children } \\
(n=26)\end{array}$ & $\begin{array}{l}\text { Probiotic: Yoghurt } \\
\text { containing L. delbrueckii } \\
\text { subsp. bulgaricus, } \\
\text { S. thermophilus and } \\
\text { L. paracasei A } \\
\text { Placebo: pasteurised } \\
\text { yoghurt }\end{array}$ & Faeces & $\begin{array}{l}\text { Conventional } \\
\text { culturing } \\
\text { RAPD-PCR } \\
\text { DGGE }\end{array}$ & $\begin{array}{l}\text { Probiotic-treated group: } \\
\text { No significant effect on } \\
\text { dominant microbiota } \\
\text { composition } \\
\text { GI survival and transiently } \\
\text { colonization by L. paracasei A }\end{array}$ & $\begin{array}{l}\text { Marzotto et al. } \\
\text { (2006) }\end{array}$ \\
\hline $\begin{array}{l}\text { Preterm infants } \\
(n=69)\end{array}$ & $\begin{array}{l}\text { Probiotic: } B \text {. animalis } \\
\text { subsp. lactis } \mathrm{Bb}-12 \\
\text { Placebo: only carrier } \\
\text { material }\end{array}$ & Faeces & $\begin{array}{l}\text { Conventional } \\
\text { culturing } \\
\text { FISH }\end{array}$ & $\begin{array}{l}\text { Probiotic-treated group: } \\
\uparrow \text { Bifidobacterium }\end{array}$ & $\begin{array}{l}\text { Mohan et al. } \\
\text { (2006) }\end{array}$ \\
\hline
\end{tabular}


Table 7 continued

\begin{tabular}{|c|c|c|c|c|c|}
\hline Population & $\begin{array}{l}\text { Study groups } \\
\text { (based on treatment) }\end{array}$ & $\begin{array}{l}\text { Study } \\
\text { material }\end{array}$ & $\begin{array}{l}\text { Analytical } \\
\text { methods }\end{array}$ & Key findings & References \\
\hline $\begin{array}{l}\text { Healthy adults } \\
\quad(n=12)\end{array}$ & $\begin{array}{l}\text { Probiotic: yoghurt } \\
\text { containing L. delbrueckii } \\
\text { subsp. bulgaricus, } \\
\text { S. thermophilus and } \\
\text { B. animalis } \text { DN-173 } 010 \\
\text { Probiotic: } \text { B. animalis } \\
\text { DN-173 } 010 \text { (lyophilised) }\end{array}$ & Faeces & $\begin{array}{l}\text { Conventional } \\
\text { culturing } \\
\text { Colony } \\
\text { immunoblotting } \\
\text { DGGE } \\
\text { FISH }\end{array}$ & $\begin{array}{l}\text { Both probiotic-treated groups: } \\
\text { No significant effect on } \\
\text { dominant microbiota } \\
\text { composition } \\
\text { GI survival and transiently } \\
\text { colonization by } B \text {. animalis }\end{array}$ & $\begin{array}{l}\text { Rochet et al. } \\
\text { (2008) }\end{array}$ \\
\hline $\begin{array}{l}\text { Healthy adults } \\
\quad(n=30)\end{array}$ & $\begin{array}{l}\text { Prebiotic: lactulose } \\
\text { Probiotic: } S . \text { boulardii } \\
\text { Synbiotic: lactulose and } \\
\text { S. boulardii } \\
\text { Placebo: maltodextrin }\end{array}$ & Faeces & $\begin{array}{l}\text { DGGE } \\
\text { Group-specific } \\
\text { qPCR }\end{array}$ & $\begin{array}{l}\text { Prebiotic-treated group: } \\
\uparrow B \text {. adolescentis } \\
\uparrow \text { Bifidobacterium } \\
\text { Probiotic/synbiotic-treated } \\
\text { group: } \\
\text { No changes }\end{array}$ & $\begin{array}{l}\text { Vanhoutte } \\
\text { et al. (2006) }\end{array}$ \\
\hline $\begin{array}{l}\text { Healthy elderly } \\
\qquad(n=55)\end{array}$ & $\begin{array}{l}\text { Probiotic: fermented oat } \\
\text { drink containing } \\
\text { B. longum } 46 \text { and } \\
\text { B. longum 2C } \\
\text { Probiotic: fermented oat } \\
\text { drink containing } \\
\text { B. animalis subsp. lactis } \\
\text { Bb-12 } \\
\text { Placebo: only fermented oat } \\
\text { drink }\end{array}$ & Faeces & $\begin{array}{l}\text { Species-specific } \\
\text { qPCR }\end{array}$ & $\begin{array}{l}\text { Probiotic-treated group } \\
\quad(B . \text { longum }): \\
\uparrow B . \text { adolescentis } \\
\uparrow B . \text { catenulatum } \\
\text { Probiotic-treated group } \\
\quad(B . \text { animalis }): \\
\uparrow B . \text { animalis }\end{array}$ & $\begin{array}{l}\text { Ouwehand } \\
\text { et al. (2008) }\end{array}$ \\
\hline $\begin{array}{l}\text { Healthy adults } \\
\quad(n=14)\end{array}$ & $\begin{array}{l}\text { Probiotic: encapsulated } \\
\text { L. rhamnosus } \mathrm{R} 11 \text { and } \\
\text { L. acidophilus } \mathrm{R} 52\end{array}$ & Faeces & $\begin{array}{l}\text { Conventional } \\
\text { culturing } \\
\text { qPCR }\end{array}$ & $\begin{array}{l}\text { No significant effect on } \\
\text { dominant microbiota } \\
\text { composition } \\
\text { GI survival and transiently } \\
\text { colonization by L. rhamnosus }\end{array}$ & $\begin{array}{l}\text { Firmesse et al. } \\
\text { (2008) }\end{array}$ \\
\hline $\begin{array}{l}\text { Healthy adults } \\
\qquad(n=79)\end{array}$ & $\begin{array}{l}\text { Probiotic: yoghurt } \\
\text { containing L. delbrueckii } \\
\text { subsp. bulgaricus and } S . \\
\text { thermophilus } \\
\text { Placebo: pasteurised } \\
\text { yoghurt } \\
\text { Control: no yoghurt }\end{array}$ & Faeces & $\begin{array}{l}\text { DGGE } \\
\text { qPCR }\end{array}$ & $\begin{array}{l}\text { Probiotic-treated group: } \\
\uparrow \text { lactic acid bacteria } \\
\uparrow C \text {. perfringens } \\
\text { Yoghurt-receiving groups: } \\
\downarrow \text { Bacteroides group }\end{array}$ & $\begin{array}{l}\text { García-Albiach } \\
\text { et al. (2008) }\end{array}$ \\
\hline $\begin{array}{l}\text { Healthy adults } \\
\text { on antibiotic } \\
\text { treatment } \\
(n=40)\end{array}$ & $\begin{array}{l}\text { Probiotic: B. animalis } \\
\text { subsp. lactis B1-04, } \\
\text { B. animalis subsp. lactis } \\
\text { Bi-07, L. acidophilus } \\
\text { NCFM, L. paracasei } \\
\text { Lpc-37, B. bifidum Bb-02 } \\
\text { and maltodextran } \\
\text { Placebo: only maltodextran }\end{array}$ & Faeces & $\begin{array}{l}\text { Conventional } \\
\text { culturing } \\
\text { T-RFLP }\end{array}$ & $\begin{array}{l}\text { Probiotic-treated group: } \\
\text { A more rapid return to } \\
\text { pre-antibiotic microbiota } \\
\text { composition } \\
\uparrow \text { Enterobacteriaceae } \\
\uparrow \text { Bifidobacterium }\end{array}$ & $\begin{array}{r}\text { Engelbrektson } \\
\text { et al. (2009) }\end{array}$ \\
\hline $\begin{array}{l}\text { Healthy elderly } \\
\qquad(n=66)\end{array}$ & $\begin{array}{l}\text { Probiotic: fermented oat } \\
\text { drink containing } \\
\text { B. longum } 46 \text { and } \\
\text { B. longum } 2 \mathrm{C} \\
\text { Placebo: non-fermented } \\
\text { oat drink }\end{array}$ & Faeces & $\begin{array}{l}\text { Conventional } \\
\text { culturing } \\
\text { Species-specific } \\
\text { qPCR }\end{array}$ & $\begin{array}{l}\text { Probiotic-treated group: } \\
\text { Significant change in } \\
\text { Bifidobacterium communities } \\
\text { ( } \uparrow \text { B. catenulatum, B. bifidum } \\
\text { and } B . \text { breve) }\end{array}$ & $\begin{array}{l}\text { Lahtinen et al. } \\
\text { (2009) }\end{array}$ \\
\hline
\end{tabular}

$D G G E$ denaturing gradient gel electrophoresis, FISH fluorescence in situ hybridisation, $q P C R$ quantitative polymerase chain reaction, $R A P D$ $P C R$ random amplification of polymorphic DNA polymerase chain reaction, $T$-RFLP terminal-restriction fragment length polymorphism 
The effectiveness of probiotic intervention has been studied in a number of human diseases, including IBD (CD, UC and pouchitis), IBS, constipation, diarrhoea (including AAD), colon cancer, cardiovascular disease, NEC, allergic diseases, obesity and metabolic disorders and these have been the subject of systematic reviews as well as Cochrane reviews (Gareau et al. 2010; Iannitti and Palmieri 2010; Pham et al. 2008; Sanz et al. 2010; Weichselbaum 2010). With the possible exception of NEC and pouchitis, variable clinical effects are found. One, and probably the most important reason for the variable clinical effects is the variation in probiotic species and strains that are being used. On top of that, there is a lack of standardised methods for the study of the intestinal microbiota (e.g. sample collection, sample storage and analysis methods), which makes it almost impossible to directly compare findings from different groups. Apart from the large variety of probiotic species and strains, also different dosages of probiotic microorganisms are used, or combinations of probiotic species and strains, or prebiotic supplements can be added. In addition, the populations of interest can be relatively heterogeneous since health and disease are not always well defined. At the same time, host-dependent factors (e.g. host genotype) may have an influence on the effectiveness of intestinal microbiota modulation by probiotics. Finally, most clinical studies have included only a small number of patients and used short-term intervention periods. All of this, in combination with the fact that the intestinal microbiota composition is diverse and maybe even unique for each individual, makes it problematic to observe general changes in microbiota composition as result of probiotic intervention.

In the early days of probiotic research, it was thought that decreased intestinal microbial diversity could be a direct cause of gastrointestinal disease. In such a concept, probiotic intervention should be aimed at increasing this diversity, which would be sufficient to resolve the clinical problem. For some diseases such as IBD, there is indeed evidence for a decreased diversity (Dicksved et al. 2008; Nishikawa et al. 2009; Qin et al. 2010). By contrast, a recent culture-independent study shows a higher richness and diversity of bacteria in the faeces of autistic individuals compared with healthy controls (Finegold et al. 2010). Nowadays, it is recognised that the interaction between intestinal microbiota and the host is more complex than just a high or low microbial diversity. Thus, no general statements can be made on the role of microbial diversity in health and disease, since different microbe-host interactions are involved in the pathophysiology of different diseases. Knowledge of the molecular and physiological mechanisms behind specific diseases and aberrations that are associated with microbial dysbiosis will contribute to the development of tailor-made probiotics designed for specific interventions.

Application of high-throughput molecular approaches in probiotic research

New insights in the potential effect of probiotic intervention on the intestinal microbiota can be obtained by application of high-throughput molecular approaches in probiotic research. An example is provided by a study in which the effectiveness of daily probiotic supplementation of Lactobacillus rhamnosus GG (LGG) on preventing the development of early markers of asthma in a human clinical study was examined (Cabana et al. 2007). The probiotic bacterium LGG is one of the most widely used probiotic microorganisms and has been used in a large number of clinical trials. An explanation for its probiotic properties has recently been provided by its genomic characterisation revealing the presence of mucus binding pili in LGG that are assumed to interact with the host (Kankainen et al. 2009). A phylogenetic microarray analysis was used to study the effect of LGG abundance on the bacterial community structure of stool samples of 6-monthold infants (Cox et al. 2010). Since the researchers were blinded to the treatment of the infants (probiotic or placebo), the effect of LGG administration on LGG abundance and intestinal microbiota composition could not be examined. However, cluster analysis of the microarray data demonstrated that LGG abundance was associated with a distinct community composition. Communities with high relative abundance of LGG showed an increased relative abundance of a large number of bacterial taxa and the majority of these taxa were phylogenetically clustered. In addition, there was a significant difference in evenness of the intestinal microbiota between samples containing a low or high abundance of LGG. It was hypothesised that a possible mechanism of the probiotic action of LGG is the stimulation of a stable, even and functionally redundant microbiota and facilitating the colonisation by other beneficial microorganisms (Kankainen et al. 2009). Whether the ability of pili of LGG to bind to intestinal mucosal surfaces is important in this respect remains to be determined.

Recently, high-throughput metagenomic sequencing was used to relate the effect of probiotic intervention to microbiota composition (Veiga et al. 2010). It was demonstrated that consumption of a fermented milk product supplemented with Bifidobacterium animalis subsp. lactis (BFMP) induced some specific metabolic shifts in an ulcerative colitis mouse model. In addition, it was shown that the immune status of the mice had an effect on the shifts in the composition of the intestinal microbiota. 
Moreover, subsets of mice could be identified based on microbiota composition that clustered together corresponding to effectiveness of the BFMP treatment. These results reinforce the notion that the composition of the endogenous intestinal microbiota plays an important role in the host response to the probiotic intervention, thereby influencing the effectiveness of probiotic intervention. In this study, it was also observed that $B F M P$ consumption resulted in a metabolic shift; a decreased caecal $\mathrm{pH}$ and alteration in short- chain fatty acid profiles. It must be noted, however, that these beneficial effects cannot be directly linked to the activity of this specific Bifidobacterium strain since a non-fermented milk product was used as control product. Overall, the data support the hypothesis that probiotics are not only able to influence the composition, but also the metabolic activity of the intestinal microbiota (De Preter et al. 2010). Both of these effects need to be studied separately to get a complete picture of the influence of probiotic intervention on the intestinal microbiota. This is also emphasised in a recent study in which the effect of a specific synbiotic product on the intestinal microbiota was examined (Vitali et al. 2010). This study showed no influence on the composition of dominant faecal microbiota, but significant changes in faecal metabolic profiles were observed. These results suggest that synbiotic intervention is able to affect the metabolic activity of the intestinal microbiota while maintaining microbiota composition with respect to its predominant components.

\section{Conclusions}

Knowledge on the composition and diversity of a healthy microbiota and on how changes in the intestinal microbiota lead to or are associated with disease, is far from complete. More research is needed to examine the species and strain diversity in the GI tract, the diversity of microbial genes (microbiome) in the GI tract and the activity of these genes (mRNA, protein and metabolite production). For future probiotic research it is important to determine the level of compositional and functional microbial dysbiosis in relevant target populations and identify potential members of the healthy microbiota to counteract the dysbiosis. Understanding the molecular mechanisms of action attributed to commensal and pathogenic bacteria will contribute to better designed probiotic products. In the future, this knowledge can be applied in the development of tailormade probiotics designed for clearly characterised target populations.

Acknowledgments This work was partly funded by Agentschap NL, project FND-07013.
Open Access This article is distributed under the terms of the Creative Commons Attribution Noncommercial License which permits any noncommercial use, distribution, and reproduction in any medium, provided the original author(s) and source are credited.

\section{References}

Adlerberth I, Wold AE (2009) Establishment of the gut microbiota in Western infants. Acta Paediatr 98(2):229-238

Ahmed S, Macfarlane GT, Fite A, McBain AJ, Gilbert P, Macfarlane S (2007) Mucosa-associated bacterial diversity in relation to human terminal ileum and colonic biopsy samples. Appl Environ Microbiol 73(22):7435-7442

Andoh A, Sakata S, Koizumi Y, Mitsuyama K, Fujiyama Y, Benno Y (2007) Terminal restriction fragment length polymorphism analysis of the diversity of fecal microbiota in patients with ulcerative colitis. Inflamm Bowel Dis 13(8):955-962

Andoh A, Tsujikawa T, Sasaki M, Mitsuyama K, Suzuki Y, Matsui T, Matsumoto T, Benno Y, Fujiyama Y (2008) Fecal microbiota profile of Crohn's disease determined by terminal restriction fragment length polymorphism (t-rflp) analysis. Aliment Pharmacol Ther 29:75-82

Armougom F, Henry M, Vialettes B, Raccah D, Raoult D (2009) Monitoring bacterial community of human gut microbiota reveals an increase in Lactobacillus in obese patients and Methanogens in anorexic patients. PLoS One 4(9):e7125

Atuma C, Strugala V, Allen A, Holm L (2001) The adherent gastrointestinal mucus gel layer: thickness and physical state in vivo. Am J Physiol Gastrointest Liver Physiol 280(5):G922-G929

Audia JP, Webb CC, Foster JW (2001) Breaking through the acid barrier: an orchestrated response to proton stress by enteric bacteria. Int J Med Microbiol 291(2):97-106

Aura AM, Mattila I, Hyötyläinen T, Gopalacharyulu P, Bounsaythip C, Orešič M, Oksman-Caldentey KM (2011) Drug metabolome of the Simvastatin formed by human intestinal microbiota in vitro. Mol Biosyst 7(2):437-446

Bäckhed F, Ding H, Wang T, Hooper LV, Koh GY, Nagy A, Semenkovich CF, Gordon JI (2004) The gut microbiota as an environmental factor that regulates fat storage. Proc Natl Acad Sci USA 101(44):15718-15723

Bäckhed F, Manchester JK, Semenkovich CF, Gordon JI (2007) Mechanisms underlying the resistance to diet-induced obesity in germ-free mice. Proc Natl Acad Sci USA 104(3):979-984

Balamurugan R, George G, Kabeerdoss J, Hepsiba J, Chandragunasekaran AM, Ramakrishna BS (2010) Quantitative differences in intestinal Faecalibacterium prausnitzii in obese Indian children. Br J Nutr 103(3):335-338

Barbara G, Stanghellini V, Brandi G, Cremon C, Di Nardo G, De Giorgio R, Corinaldesi R (2005) Interactions between commensal bacteria and gut sensorimotor function in health and disease. Am J Gastroenterol 100(11):2560-2568

Bartosch S, Fite A, Macfarlane GT, McMurdo ME (2004) Characterization of bacterial communities in feces from healthy elderly volunteers and hospitalized elderly patients by using real-time PCR and effects of antibiotic treatment on the fecal microbiota. Appl Environ Microbiol 70(6):3575-3581

Baumgart M, Dogan B, Rishniw M, Weitzman G, Bosworth B, Yantiss R, Orsi RH, Wiedmann M, McDonough P, Kim SG, Berg D, Schukken Y, Scherl E, Simpson KW (2007) Culture independent analysis of ileal mucosa reveals a selective increase in invasive Escherichia coli of novel phylogeny relative to depletion of Clostridiales in Crohn's disease involving the ileum. ISME J 1(5):403-418 
Biagi E, Nylund L, Candela M, Ostan R, Bucci L, Pini E, Nikkïla J, Monti D, Satokari R, Franceschi C, Brigidi P, De Vos W (2010) Through ageing, and beyond: gut microbiota and inflammatory status in seniors and centenarians. PLoS One 5(5):e10667

Bibiloni R, Mangold M, Madsen KL, Fedorak RN, Tannock GW (2006) The bacteriology of biopsies differs between newly diagnosed, untreated, Crohn's disease and ulcerative colitis patients. J Med Microbiol 55(Pt 8):1141-1149

Björkstén B, Naaber P, Sepp E, Mikelsaar M (1999) The intestinal microflora in allergic Estonian and Swedish 2-year-old children. Clin Exp Allergy 29(3):342-346

Björkstén B, Sepp E, Julge K, Voor T, Mikelsaar M (2001) Allergy development and the intestinal microflora during the first year of life. J Allergy Clin Immunol 108(4):516-520

Boesten RJ, De Vos WM (2008) Interactomics in the human intestine: Lactobacilli and Bifidobacteria make a difference. J Clin Gastroenterol 42(Suppl 3, Pt 2):S163-S167

Booijink CC, Zoetendal EG, Kleerebezem M, De Vos WM (2007) Microbial communities in the human small intestine: coupling diversity to metagenomics. Future Microbiol 2(3):285-295

Booijink CC, El-Aidy S, Rajilić-Stojanović M, Heilig HG, Troost FJ, Smidt H, Kleerebezem M, De Vos WM, Zoetendal EG (2010) High temporal and inter-individual variation detected in the human ileal microbiota. Environ Microbiol 12(12):3213-3227

Buddington RK, Sangild PT (2011) Development of the mammalian gastrointestinal tract, the resident microbiota, and the role of diet in early life. J Anim Sci 89:1506-1519

Cabana MD, McKean M, Wong AR, Chao C, Caughey AB (2007) Examining the hygiene hypothesis: the Trial of Infant Probiotic Supplementation. Paediatr Perinat Epidemiol 21(Suppl 3):23-28

Cani PD, Delzenne NM (2009) The role of the gut microbiota in energy metabolism and metabolic disease. Curr Pharm Des 15(13): 1546-1558

Carroll IM, Chang YH, Park J, Sartor RB, Ringel Y (2010) Luminal and mucosal-associated intestinal microbiota in patients with diarrhea-predominant irritable bowel syndrome. Gut Pathog 2(1): 19

Cerf-Bensussan N, Gaboriau-Routhiau V (2010) The immune system and the gut microbiota: friends or foes? Nat Rev Immunol 10(10):735-744

Chang JY, Talley NJ (2011) An update on irritable bowel syndrome: from diagnosis to emerging therapies. Curr Opin Gastroenterol 27(1):72-78

Chapman CM, Gibson GR, Rowland I (2011) Health benefits of probiotics: are mixtures more effective than single strains? Eur J Nutr 50(1):1-17

Claesson MJ, Cusack S, O'Sullivan O, Greene-Diniz R, de Weerd H, Flannery E, Marchesi JR, Falush D, Dinan T, Fitzgerald G, Stanton C, van Sinderen D, O'Connor M, Harnedy N, O'Connor K, Henry C, O'Mahony D, Fitzgerald AP, Shanahan F, Twomey C, Hill C, Ross RP, O'Toole PW (2010) Microbes and Health Sackler Colloquium: Composition, variability, and temporal stability of the intestinal microbiota of the elderly. Proc Natl Acad Sci USA. Epub

Codling C, O'Mahony L, Shanahan F, Quigley EM, Marchesi JR (2010) A molecular analysis of fecal and mucosal bacterial communities in irritable bowel syndrome. Dig Dis Sci 55(2):392-397

Collado MC, Calabuig M, Sanz Y (2007) Differences between the fecal microbiota of coeliac infants and healthy controls. Curr Issues Intest Microbiol 8(1):9-14

Collado MC, Donat E, Ribes-Koninckx C, Calabuig M, Sanz Y (2008a) Imbalances in faecal and duodenal Bifidobacterium species composition in active and non-active coeliac disease. BMC Microbiol 8:232
Collado MC, Isolauri E, Laitinen K, Salminen S (2008b) Distinct composition of gut microbiota during pregnancy in overweight and normal-weight women. Am J Clin Nutr 88(4):894-899

Collado MC, Isolauri E, Laitinen K, Salminen S (2010) Effect of mother's weight on infant's microbiota acquisition, composition, and activity during early infancy: a prospective follow-up study initiated in early pregnancy. Am J Clin Nutr 92(5):1023-1030

Collins MD, Lawson PA, Willems A, Cordoba JJ, FernandezGarayzabal J, Garcia P, Cai J, Hippe H, Farrow JA (1994) The phylogeny of the genus Clostridium: proposal of five new genera and eleven new species combinations. Int $\mathrm{J}$ Syst Bacteriol 44(4):812-826

Costello EK, Lauber CL, Hamady M, Fierer N, Gordon JI, Knight R (2009) Bacterial community variation in human body habitats across space and time. Science 326(5960):1694-1697

Cowan D, Meyer Q, Stafford W, Muyanga S, Cameron R, Wittwer P (2005) Metagenomic gene discovery: past, present and future. Trends Biotechnol 23(6):321-329

Cox MJ, Huang YJ, Fujimura KE, Liu JT, McKean M, Boushey HA, Segal MR, Brodie EL, Cabana MD, Lynch SV (2010) Lactobacillus casei abundance is associated with profound shifts in the infant gut microbiome. PLoS One 5(1):e8745

Darfeuille-Michaud A (2002) Adherent-invasive Escherichia coli: a putative new E. coli pathotype associated with Crohn's disease. Int J Med Microbiol 292(3-4):185-193

Darfeuille-Michaud A, Boudeau J, Bulois P, Neut C, Glasser AL, Barnich N, Bringer MA, Swidsinski A, Beaugerie L, Colombel JF (2004) High prevalence of adherent-invasive Escherichia coli associated with ileal mucosa in Crohn's disease. Gastroenterology 127(2):412-421

De Palma G, Nadal I, Medina M, Donat E, Ribes-Koninckx C, Calabuig M, Sanz Y (2010) Intestinal dysbiosis and reduced immunoglobulin-coated bacteria associated with coeliac disease in children. BMC Microbiol 10:63

De Preter V, Hamer HM, Windey K, Verbeke K (2010) The impact of pre- and/or probiotics on human colonic metabolism: does it affect human health? Mol Nutr Food Res 55(1):46-57

Dethlefsen L, Eckburg PB, Bik EM, Relman DA (2006) Assembly of the human intestinal microbiota. Trends Ecol Evol 21(9):517-523

Dethlefsen L, Huse S, Sogin ML, Relman DA (2008) The pervasive effects of an antibiotic on the human gut microbiota, as revealed by deep $16 \mathrm{~S}$ rRNA sequencing. PLoS Biol 6(11):e280

Dicksved J, Halfvarson J, Rosenquist M, Järnerot G, Tysk C, Apajalahti J, Engstrand L, Jansson JK (2008) Molecular analysis of the gut microbiota of identical twins with Crohn's disease. ISME J 2(7):716-727

Dridi B, Henry M, El Khéchine A, Raoult D, Drancourt M (2009) High prevalence of Methanobrevibacter smithii and Methanosphaera stadtmanae detected in the human gut using an improved DNA detection protocol. PLoS One 4(9):e7063

Dumas ME, Wilder SP, Bihoreau MT, Barton RH, Fearnside JF, Argoud K, D'Amato L, Wallis RH, Blancher C, Keun HC, Baunsgaard D, Scott J, Sidelmann UG, Nicholson JK, Gauguier D (2007) Direct quantitative trait locus mapping of mammalian metabolic phenotypes in diabetic and normoglycemic rat models. Nat Genet 39(5):666-672

Duncan SH, Belenguer A, Holtrop G, Johnstone AM, Flint HJ, Lobley GE (2007) Reduced dietary intake of carbohydrates by obese subjects results in decreased concentrations of butyrate and butyrate-producing bacteria in feces. Appl Environ Microbiol 73(4):1073-1078

Duncan SH, Lobley GE, Holtrop G, Ince J, Johnstone AM, Louis P, Flint HJ (2008) Human colonic microbiota associated with diet, obesity and weight loss. Int J Obes (Lond) 32(11):1720-1724 
Eckburg PB, Bik EM, Bernstein CN, Purdom E, Dethlefsen L, Sargent M, Gill SR, Nelson KE, Relman DA (2005) Diversity of the human intestinal microbial flora. Science 308(5728):16351638

Engelbrektson A, Korzenik JR, Pittler A, Sanders ME, Klaenhammer TR, Leyer G, Kitts CL (2009) Probiotics to minimize the disruption of faecal microbiota in healthy subjects undergoing antibiotic therapy. J Med Microbiol 58(Pt 5):663-670

FAO/WHO (2002) Working group report on drafting guidelines for the evaluation of probiotics in food. London, Ontario, Canada

Fava F, Danese S (2011) Intestinal microbiota in inflammatory bowel disease: Friend of foe? World J Gastroenterol 17(5):557-566

Favier CF, Vaughan EE, De Vos WM, Akkermans AD (2002) Molecular monitoring of succession of bacterial communities in human neonates. Appl Environ Microbiol 68(1):219-226

Ferguson RM, Merrifield DL, Harper GM, Rawling MD, Mustafa S, Picchietti S, Balćazar JL, Davies SJ (2010) The effect of Pediococcus acidilactici on the gut microbiota and immune status of on-growing red tilapia (Oreochromis niloticus). J Appl Microbiol 109(3):851-862

Finegold SM, Molitoris D, Song Y, Liu C, Vaisanen ML, Bolte E, McTeague M, Sandler R, Wexler H, Marlowe EM, Collins MD, Lawson PA, Summanen P, Baysallar M, Tomzynski TJ, Read E, Johnson E, Rolfe R, Nasir P, Shah H, Haake DA, Manning P, Kaul A (2002) Gastrointestinal microflora studies in late-onset autism. Clin Infect Dis 35(Suppl 1):S6-S16

Finegold SM, Dowd SE, Gontcharova V, Liu C, Henley KE, Wolcott RD, Youn E, Summanen PH, Granpeesheh D, Dixon D, Liu M, Molitoris DR, Green JA III (2010) Pyrosequencing study of fecal microflora of autistic and control children. Anaerobe 16(4):444 453

Firmesse O, Mogenet A, Bresson JL, Corthier G, Furet JP (2008) Lactobacillus rhamnosus R11 consumed in a food supplement survived human digestive transit without modifying microbiota equilibrium as assessed by real-time polymerase chain reaction. J Mol Microbiol Biotechnol 14(1-3):90-99

Fooks LJ, Gibson GR (2002) Probiotics as modulators of the gut flora. Br J Nutr 88(Suppl 1):S39-S49

Frank DN, St Amand AL, Feldman RA, Boedeker EC, Harpaz N, Pace NR (2007) Molecular-phylogenetic characterization of microbial community imbalances in human inflammatory bowel diseases. Proc Natl Acad Sci USA 104(34):13780-13785

Franks AH, Harmsen HJ, Raangs GC, Jansen GJ, Schut F, Welling GW (1998) Variations of bacterial populations in human feces measured by fluorescent in situ hybridization with group-specific $16 \mathrm{~S}$ rRNA-targeted oligonucleotide probes. Appl Environ Microbiol 64(9):3336-3345

Fuentes S, Egert M, Jiménez-Valera M, Ramos-Cormenzana A, RuizBravo A, Smidt H, Monteoliva-Sanchez M (2008) Administration of Lactobacillus casei and Lactobacillus plantarum affects the diversity of murine intestinal lactobacilli, but not the overall bacterial community structure. Res Microbiol 159(4):237-243

García-Albiach R, Pozuelo de Felipe MJ, Angulo S, Morosini MI, Bravo D, Baquero F, del Campo R (2008) Molecular analysis of yogurt containing Lactobacillus delbrueckii subsp. bulgaricus and Streptococcus thermophilus in human intestinal microbiota. Am J Clin Nutr 87(1):91-96

Gareau MG, Sherman PM, Walker WA (2010) Probiotics and the gut microbiota in intestinal health and disease. Nat Rev Gastroenterol Hepatol 7(9):503-514

Garrett WS, Gallini CA, Yatsunenko T, Michaud M, DuBois A, Delaney ML, Punit S, Karlsson M, Bry L, Glickman JN, Gordon JI, Onderdonk AB, Glimcher LH (2010) Enterobacteriaceae act in concert with the gut microbiota to induce spontaneous and maternally transmitted colitis. Cell Host Microbe 8(3):292-300
Gill SR, Pop M, Deboy RT, Eckburg PB, Turnbaugh PJ, Samuel BS, Gordon JI, Relman DA, Fraser-Liggett CM, Nelson KE (2006) Metagenomic analysis of the human distal gut microbiome. Science 312(5778):1355-1359

Gophna U, Sommerfeld K, Gophna S, Doolittle WF, Veldhuyzen van Zanten SJ (2006) Differences between tissue-associated intestinal microfloras of patients with Crohn's disease and ulcerative colitis. J Clin Microbiol 44(11):4136-4141

Gore C, Munro K, Lay C, Bibiloni R, Morris J, Woodcock A, Custovic A, Tannock GW (2008) Bifidobacterium pseudocatenulatum is associated with atopic eczema: a nested case-control study investigating the fecal microbiota of infants. J Allergy Clin Immunol 121(1):135-140

Gosalbes MJ, Durbán A, Pignatelli M, Abellan JJ, Jiménez-Hernández N, Pérez-Cobas AE, Latorre A, Moya A (2011) Metatranscriptomic approach to analyze the functional human gut microbiota. PLoS One 6(3):e17447

Hamer HM, Jonkers D, Venema K, Vanhoutvin S, Troost FJ, Brummer RJ (2008) Review article: the role of butyrate on colonic function. Aliment Pharmacol Ther 27(2):104-119

Hansen J, Gulati A, Sartor RB (2010) The role of mucosal immunity and host genetics in defining intestinal commensal bacteria. Curr Opin Gastroenterol 26(6):564-571

Harmsen HJ, Wildeboer-Veloo AC, Raangs GC, Wagendorp AA, Klijn N, Bindels JG, Welling GW (2000) Analysis of intestinal flora development in breast-fed and formula-fed infants by using molecular identification and detection methods. J Pediatr Gastroenterol Nutr 30(1):61-67

Hartman AL, Lough DM, Barupal DK, Fiehn O, Fishbein T, Zasloff M, Eisen JA (2009) Human gut microbiome adopts an alternative state following small bowel transplantation. Proc Natl Acad Sci USA 106(40):17187-17192

Hayashi H, Takahashi R, Nishi T, Sakamoto M, Benno Y (2005) Molecular analysis of jejunal, ileal, caecal and recto-sigmoidal human colonic microbiota using $16 \mathrm{~S}$ rRNA gene libraries and terminal restriction fragment length polymorphism. J Med Microbiol 54(Pt 11):1093-1101

Hildebrandt MA, Hoffmann C, Sherrill-Mix SA, Keilbaugh SA, Hamady M, Chen YY, Knight R, Ahima RS, Bushman F, Wu GD (2009) High-fat diet determines the composition of the murine gut microbiome independently of obesity. Gastroenterology 137(5):1716-1724

Holmes E, Loo RL, Stamler J, Bictash M, Yap IK, Chan Q, Ebbels T, De Iorio M, Brown IJ, Veselkov KA, Daviglus ML, Kesteloot H, Ueshima H, Zhao L, Nicholson JK, Elliott P (2008) Human metabolic phenotype diversity and its association with diet and blood pressure. Nature 453(7193):396-400

Holzapfel WH, Haberer P, Snel J, Schillinger U, Huis in't Veld JH (1998) Overview of gut flora and probiotics. Int J Food Microbiol 41(2):85-101

Iannitti T, Palmieri B (2010) Therapeutical use of probiotic formulations in clinical practice. Clin Nutr 29(6):701-725

Iwaya A, Iiai T, Okamoto H, Ajioka Y, Yamamoto T, Asahara T, Nomoto K, Hatakeyama K (2006) Change in the bacterial flora of pouchitis. Hepatogastroenterology 53(67):55-59

Jernberg C, Löfmark S, Edlund C, Jansson JK (2007) Long-term ecological impacts of antibiotic administration on the human intestinal microbiota. ISME J 1(1):56-66

Jernberg C, Löfmark S, Edlund C, Jansson JK (2010) Long-term impacts of antibiotic exposure on the human intestinal microbiota. Microbiology 156(Pt 11):3216-3223

Jiménez E, Fernández L, Marín ML, Martín R, Odriozola JM, NuenoPalop C, Narbad A, Olivares M, Xaus J, Rodríguez JM (2005) Isolation of commensal bacteria from umbilical cord blood of healthy neonates born by cesarean section. Curr Microbiol 51(4):270-274 
Jiménez E, Marín ML, Martín R, Odriozola JM, Olivares M, Xaus J, Fernández L, Rodríguez JM (2008) Is meconium from healthy newborns actually sterile? Res Microbiol 159(3):187-193

Johansson ME, Phillipson M, Petersson J, Velcich A, Holm L, Hansson GC (2008) The inner of the two Muc2 mucin-dependent mucus layers in colon is devoid of bacteria. Proc Natl Acad Sci USA 105(39):15064-15069

Johansson ME, Holmén Larsson JM, Hansson GC (2010) Microbes and Health Sackler Colloquium: The two mucus layers of colon are organized by the MUC2 mucin, whereas the outer layer is a legislator of host-microbial interactions. Proc Natl Acad Sci USA. Epub

Joossens M, Huys G, Cnockaert M, De Preter V, Verbeke K, Rutgeerts P, Vandamme P, Vermeire S (2011) Dysbiosis of the faecal microbiota in patients with Crohn's disease and their unaffected relatives. Gut 60(5):631-637

Kajander K, Myllyluoma E, Rajilić-Stojanović M, Kyrönpalo S, Rasmussen M, Järvenpää S, Zoetendal EG, De Vos WM, Vapaatalo H, Korpela R (2008) Clinical trial: multispecies probiotic supplementation alleviates the symptoms of irritable bowel syndrome and stabilizes intestinal microbiota. Aliment Pharmacol Ther 27(1):48-57

Kalliomäki M, Kirjavainen P, Eerola E, Kero P, Salminen S, Isolauri $\mathrm{E}$ (2001) Distinct patterns of neonatal gut microflora in infants in whom atopy was and was not developing. J Allergy Clin Immunol 107(1):129-134

Kalliomäki M, Collado MC, Salminen S, Isolauri E (2008) Early differences in fecal microbiota composition in children may predict overweight. Am J Clin Nutr 87(3):534-538

Kanazawa K, Konishi F, Mitsuoka T, Terada A, Itoh K, Narushima S, Kumemura M, Kimura H (1996) Factors influencing the development of sigmoid colon cancer. Bacteriologic and biochemical studies. Cancer 77(8 Suppl):1701-1706

Kang S, Denman SE, Morrison M, Yu Z, Doré J, Leclerc M, McSweeney CS (2010) Dysbiosis of fecal microbiota in Crohn's disease patients as revealed by a custom phylogenetic microarray. Inflamm Bowel Dis 16(12):2034-2042

Kankainen M, Paulin L, Tynkkynen S, von Ossowski I, Reunanen J, Partanen P, Satokari R, Vesterlund S, Hendrickx AP, Lebeer S, De Keersmaecker SC, Vanderleyden J, Hämäläinen T, Laukkanen S, Salovuori N, Ritari J, Alatalo E, Korpela R, MattilaSandholm T, Lassig A, Hatakka K, Kinnunen KT, Karjalainen H, Saxelin M, Laakso K, Surakka A, Palva A, Salusjärvi T, Auvinen P, De Vos WM (2009) Comparative genomic analysis of Lactobacillus rhamnosus GG reveals pili containing a humanmucus binding protein. Proc Natl Acad Sci USA 106(40): 17193-17198

Karantanos T, Markoutsaki T, Gazouli M, Anagnou NP, Karamanolis DG (2010) Current insights into the pathophysiology of Irritable Bowel Syndrome. Gut Pathog 2(1):3

Kassinen A, Krogius-Kurikka L, Mäkivuokko H, Rinttilä T, Paulin L, Corander J, Malinen E, Apajalahti J, Palva A (2007) The fecal microbiota of irritable bowel syndrome patients differs significantly from that of healthy subjects. Gastroenterology 133(1):24-33

Kerckhoffs AP, Samsom M, van der Rest ME, de Vogel J, Knol J, Ben-Amor K, Akkermans LM (2009) Lower bifidobacteria counts in both duodenal mucosa-associated and fecal microbiota in irritable bowel syndrome patients. World $\mathrm{J}$ Gastroenterol 15(23):2887-2892

Kerckhoffs AP, Ben-Amor K, Samsom M, van der Rest ME, de Vogel J, Knol J, Akkermans LM (2010) Molecular analysis of faecal and duodenal samples reveals significantly higher prevalence and numbers of Pseudomonas aeruginosa in IBS. J Med Microbiol 60:236-245
Kim YS, Ho SB (2010) Intestinal goblet cells and mucins in health and disease: recent insights and progress. Curr Gastroenterol Rep 12(5):319-330

Kinross JM, Darzi AW, Nicholson JK (2011) Gut microbiome-host interactions in health and disease. Genome Med 3(3):14

Kirjavainen PV, Apostolou E, Arvola T, Salminen SJ, Gibson GR, Isolauri E (2001) Characterizing the composition of intestinal microflora as a prospective treatment target in infant allergic disease. FEMS Immunol Med Microbiol 32(1):1-7

Klaassens ES, De Vos WM, Vaughan EE (2007) Metaproteomics approach to study the functionality of the microbiota in the human infant gastrointestinal tract. Appl Environ Microbiol 73(4):1388-1392

Klaassens ES, Boesten RJ, Haarman M, Knol J, Schuren FH, Vaughan EE, De Vos WM (2009) Mixed-species genomic microarray analysis of fecal samples reveals differential transcriptional responses of bifidobacteria in breast- and formula-fed infants. Appl Environ Microbiol 75(9):2668-2676

Kleerebezem M, Vaughan EE (2009) Probiotic and gut lactobacilli and bifidobacteria: molecular approaches to study diversity and activity. Annu Rev Microbiol 63:269-290

Kleessen B, Kroesen AJ, Buhr HJ, Blaut M (2002) Mucosal and invading bacteria in patients with inflammatory bowel disease compared with controls. Scand J Gastroenterol 37(9):1034-1041

Koenig JE, Spor A, Scalfone N, Fricker AD, Stombaugh J, Knight R, Angenent LT, Ley RE (2010) Microbes and Health Sackler Colloquium: Succession of microbial consortia in the developing infant gut microbiome. Proc Natl Acad Sci USA Epub

Koide A, Yamaguchi T, Odaka T, Koyama H, Tsuyuguchi T, Kitahara H, Ohto M, Saisho H (2000) Quantitative analysis of bowel gas using plain abdominal radiograph in patients with irritable bowel syndrome. Am J Gastroenterol 95(7):1735-1741

Komanduri S, Gillevet PM, Sikaroodi M, Mutlu E, Keshavarzian A (2007) Dysbiosis in pouchitis: evidence of unique microfloral patterns in pouch inflammation. Clin Gastroenterol Hepatol $5(3): 352-360$

Koning CJ, Jonkers D, Smidt H, Rombouts F, Pennings HJ, Wouters E, Stobberingh E, Stockbrügger R (2010) The effect of a multispecies probiotic on the composition of the faecal microbiota and bowel habits in chronic obstructive pulmonary disease patients treated with antibiotics. Br J Nutr 103(10):1452-1460

Kotlowski R, Bernstein CN, Sepehri S, Krause DO (2007) High prevalence of Escherichia coli belonging to the B2+D phylogenetic group in inflammatory bowel disease. Gut 56(5):669-675

Kovatcheva-Datchary P, Egert M, Maathuis A, Rajilić-Stojanović M, De Graaf AA, Smidt H, De Vos WM, Venema K (2009) Linking phylogenetic identities of bacteria to starch fermentation in an in vitro model of the large intestine by RNA-based stable isotope probing. Environ Microbiol 11(4):914-926

Krogius-Kurikka L, Lyra A, Malinen E, Aarnikunnas J, Tuimala J, Paulin L, Mäkivuokko H, Kajander K, Palva A (2009) Microbial community analysis reveals high level phylogenetic alterations in the overall gastrointestinal microbiota of diarrhoea-predominant irritable bowel syndrome sufferers. BMC Gastroenterol 9:95

Kurokawa K, Itoh T, Kuwahara T, Oshima K, Toh H, Toyoda A, Takami H, Morita H, Sharma VK, Srivastava TP, Taylor TD, Noguchi H, Mori H, Ogura Y, Ehrlich DS, Itoh K, Takagi T, Sakaki Y, Hayashi T, Hattori M (2007) Comparative metagenomics revealed commonly enriched gene sets in human gut microbiomes. DNA Res 14(4):169-181

Lahtinen SJ, Tammela L, Korpela J, Parhiala R, Ahokoski H, Mykkänen H, Salminen SJ (2009) Probiotics modulate the Bifidobacterium microbiota of elderly nursing home residents. Age (Dordr) 31(1):59-66 
Larsen N, Vogensen FK, van den Berg FW, Nielsen DS, Andreasen AS, Pedersen BK, Al-Soud WA, Sørensen SJ, Hansen LH, Jakobsen M (2010) Gut microbiota in human adults with type 2 diabetes differs from non-diabetic adults. PLoS One 5(2):e9085

Lepage P, Seksik P, Sutren M, de la Cochetière MF, Jian R, Marteau P, Doré J (2005) Biodiversity of the mucosa-associated microbiota is stable along the distal digestive tract in healthy individuals and patients with IBD. Inflamm Bowel Dis 11(5):473-480

Ley RE (2010) Obesity and the human microbiome. Curr Opin Gastroenterol 26(1):5-11

Ley RE, Bäckhed F, Turnbaugh P, Lozupone CA, Knight RD, Gordon JI (2005) Obesity alters gut microbial ecology. Proc Natl Acad Sci USA 102(31):11070-11075

Ley RE, Turnbaugh PJ, Klein S, Gordon JI (2006) Microbial ecology: human gut microbes associated with obesity. Nature 444(7122):1022-1023

Ley RE, Lozupone CA, Hamady M, Knight R, Gordon JI (2008) Worlds within worlds: evolution of the vertebrate gut microbiota. Nat Rev Microbiol 6(10):776-788

Lim M, Adams JD, Wilcox M, Finan P, Sagar P, Burke D (2009) An assessment of bacterial dysbiosis in pouchitis using terminal restriction fragment length polymorphisms of $16 \mathrm{~S}$ ribosomal DNA from pouch effluent microbiota. Dis Colon Rectum 52(8):1492-1500

Longstreth GF, Thompson WG, Chey WD, Houghton LA, Mearin F, Spiller RC (2006) Functional bowel disorders. Gastroenterology 130(5):1480-1491

López P, Gueimonde M, Margolles A, Suárez A (2010) Distinct Bifidobacterium strains drive different immune responses in vitro. Int J Food Microbiol 138(1-2):157-165

Lyra A, Rinttilä T, Nikkila J, Krogius-Kurikka L, Kajander K, Malinen E, Mättö J, Mäkelä L, Palva A (2009) Diarrhoeapredominant irritable bowel syndrome distinguishable by $16 \mathrm{~S}$ rRNA gene phylotype quantification. World J Gastroenterol 15(47):5936-5945

Mackie RI, Sghir A, Gaskins HR (1999) Developmental microbial ecology of the neonatal gastrointestinal tract. Am J Clin Nutr 69(5):1035S-1045S

Mai V, Greenwald B, Morris JG Jr, Raufman JP, Stine OC (2006) Effect of bowel preparation and colonoscopy on post-procedure intestinal microbiota composition. Gut 55(12):1822-1823

Malinen E, Rinttilä T, Kajander K, Mättö J, Kassinen A, Krogius L, Saarela M, Korpela R, Palva A (2005) Analysis of the fecal microbiota of irritable bowel syndrome patients and healthy controls with real-time PCR. Am J Gastroenterol 100(2):373382

Malinen E, Krogius-Kurikka L, Lyra A, Nikkïla J, Jääskeläinen A, Rinttilä T, Vilpponen-Salmela T, von Wright AJ, Palva A (2010) Association of symptoms with gastrointestinal microbiota in irritable bowel syndrome. World J Gastroenterol 16(36):4532-4540

Mangin I, Bonnet R, Seksik P, Rigottier-Gois L, Sutren M, Bouhnik Y, Neut C, Collins MD, Colombel JF, Marteau P, Doré J (2004) Molecular inventory of faecal microflora in patients with Crohn's disease. FEMS Microbiol Ecol 50(1):25-36

Manichanh C, Rigottier-Gois L, Bonnaud E, Gloux K, Pelletier E, Frangeul L, Nalin R, Jarrin C, Chardon P, Marteau P, Roca J, Doré J (2006) Reduced diversity of faecal microbiota in Crohn's disease revealed by a metagenomic approach. Gut 55(2):205211

Mariat D, Firmesse O, Levenez F, Guimarăes V, Sokol H, Doré J, Corthier G, Furet JP (2009) The Firmicutes/Bacteroidetes ratio of the human microbiota changes with age. BMC Microbiol 9:123

Martin FP, Sprenger N, Montoliu I, Rezzi S, Kochhar S, Nicholson JK (2010) Dietary modulation of gut functional ecology studied by fecal metabonomics. J Proteome Res 9(10):5284-5295
Martinez C, Antolin M, Santos J, Torrejon A, Casellas F, Borruel N, Guarner F, Malagelada JR (2008) Unstable composition of the fecal microbiota in ulcerative colitis during clinical remission. Am J Gastroenterol 103(3):643-648

Martinez-Medina M, Aldeguer X, Gonzalez-Huix F, Acero D, GarciaGil LJ (2006) Abnormal microbiota composition in the ileocolonic mucosa of Crohn's disease patients as revealed by polymerase chain reaction-denaturing gradient gel electrophoresis. Inflamm Bowel Dis 12(12):1136-1145

Marzotto M, Maffeis C, Paternoster T, Ferrario R, Rizzotti L, Pellegrino M, Dellaglio F, Torriani S (2006) Lactobacillus paracasei A survives gastrointestinal passage and affects the fecal microbiota of healthy infants. Res Microbiol 157(9):857-866

Matsuki T, Watanabe K, Fujimoto J, Kado Y, Takada T, Matsumoto K, Tanaka R (2004) Quantitative PCR with 16S rRNA-genetargeted species-specific primers for analysis of human intestinal bifidobacteria. Appl Environ Microbiol 70(1):167-173

Mättö J, Maunuksela L, Kajander K, Palva A, Korpela R, Kassinen A, Saarela M (2005) Composition and temporal stability of gastrointestinal microbiota in irritable bowel syndrome-a longitudinal study in IBS and control subjects. FEMS Immunol Med Microbiol 43(2):213-222

Maukonen J, Satokari R, Mättö J, Söderlund H, Mattila-Sandholm T, Saarela M (2006) Prevalence and temporal stability of selected clostridial groups in irritable bowel syndrome in relation to predominant faecal bacteria. J Med Microbiol 55(Pt 5):625-633

McFarland LV (1998) Epidemiology, risk factors and treatments for antibiotic-associated diarrhea. Dig Dis 16(5):292-307

Medina M, Izquierdo E, Ennahar S, Sanz Y (2007) Differential immunomodulatory properties of Bifidobacterium longum strains: relevance to probiotic selection and clinical applications. Clin Exp Immunol 150(3):531-538

Meijerink M, van Hemert S, Taverne N, Wels M, De Vos P, Bron PA, Savelkoul HF, van Bilsen J, Kleerebezem M, Wells JM (2010) Identification of genetic loci in Lactobacillus plantarum that modulate the immune response of dendritic cells using comparative genome hybridization. PLoS One 5(5):e10632

Merritt ME, Donaldson JR (2009) Effect of bile salts on the DNA and membrane integrity of enteric bacteria. J Med Microbiol 58(Pt 12): $1533-1541$

Mihajlovski A, Alric M, Brugère JF (2008) A putative new order of methanogenic Archaea inhabiting the human gut, as revealed by molecular analyses of the mcrA gene. Res Microbiol 159(7-8): $516-521$

Mohan R, Koebnick C, Schildt J, Schmidt S, Mueller M, Possner M, Radke M, Blaut M (2006) Effects of Bifidobacterium lactis Bb12 supplementation on intestinal microbiota of preterm infants: a double-blind, placebo-controlled, randomized study. J Clin Microbiol 44(11):4025-4031

Mondot S, Kang S, Furet JP, Aguirre de Carcer D, McSweeney C, Morrison M, Marteau P, Doré J, Leclerc M (2011) Highlighting new phylogenetic specificities of Crohn's disease microbiota. Inflamm Bowel Dis 17(1):185-192

Montesi A, García-Albiach R, Pozuelo MJ, Pintado C, Goñi I, Rotger $\mathrm{R}$ (2005) Molecular and microbiological analysis of caecal microbiota in rats fed with diets supplemented either with prebiotics or probiotics. Int J Food Microbiol 98(3):281-289

Moore WE, Moore LH (1995) Intestinal floras of populations that have a high risk of colon cancer. Appl Environ Microbiol 61(9):3202-3207

Mortensen PB, Andersen JR, Arffmann S, Krag E (1987) Short-chain fatty acids and the irritable bowel syndrome: the effect of wheat bran. Scand J Gastroenterol 22(2):185-192

Mshvildadze M, Neu J, Shuster J, Theriaque D, Li N, Mai V (2010) Intestinal microbial ecology in premature infants assessed with non-culture-based techniques. J Pediatr 156(1):20-25 
Mueller S, Saunier K, Hanisch C, Norin E, Alm L, Midtvedt T, Cresci A, Silvi S, Orpianesi C, Verdenelli MC, Clavel T, Koebnick C, Zunft HJ, Doré J, Blaut M (2006) Differences in fecal microbiota in different European study populations in relation to age, gender, and country: a cross-sectional study. Appl Environ Microbiol 72(2):1027-1033

Murphy EF, Cotter PD, Healy S, Marques TM, O’Sullivan O, Fouhy F, Clarke SF, O'Toole PW, Quigley EM, Stanton C, Ross PR, O'Doherty RM, Shanahan F (2010) Composition and energy harvesting capacity of the gut microbiota: relationship to diet, obesity and time in mouse models. Gut 59(12):1635-1642

Musso G, Gambino R, Cassader M (2010) Obesity, diabetes, and gut microbiota: the hygiene hypothesis expanded? Diabetes Care 33(10):2277-2284

Mylonaki M, Rayment NB, Rampton DS, Hudspith BN, Brostoff J (2005) Molecular characterization of rectal mucosa-associated bacterial flora in inflammatory bowel disease. Inflamm Bowel Dis 11(5):481-487

Nadal I, Donat E, Ribes-Koninckx C, Calabuig M, Sanz Y (2007) Imbalance in the composition of the duodenal microbiota of children with coeliac disease. J Med Microbiol 56( $\mathrm{Pt}$ 12): 1669-1674

Nadal I, Santacruz A, Marcos A, Warnberg J, Garagorri M, Moreno LA, Martin-Matillas M, Campoy C, Martí A, Moleres A, Delgado M, Veiga OL, García-Fuentes M, Redondo CG, Sanz Y (2009) Shifts in clostridia, bacteroides and immunoglobulincoating fecal bacteria associated with weight loss in obese adolescents. Int J Obes (Lond) 33(7):758-767

Nelson KE, Weinstock GM, Highlander SK, Worley KC, Creasy HH, Wortman JR, Rusch DB, Mitreva M, Sodergren E, Chinwalla AT, Feldgarden M, Gevers D, Haas BJ, Madupu R, Ward DV, Birren BW, Gibbs RA, Methe B, Petrosino JF, Strausberg RL, Sutton GG, White OR, Wilson RK, Durkin S, Giglio MG, Gujja S, Howarth C, Kodira CD, Kyrpides N, Mehta T, Muzny DM, Pearson M, Pepin K, Pati A, Qin X, Yandava C, Zeng Q, Zhang L, Berlin AM, Chen L, Hepburn TA, Johnson J, McCorrison J, Miller J, Minx P, Nusbaum C, Russ C, Sykes SM, Tomlinson CM, Young S, Warren WC, Badger J, Crabtree J, Markowitz VM, Orvis J, Cree A, Ferriera S, Fulton LL, Fulton RS, Gillis M, Hemphill LD, Joshi V, Kovar C, Torralba M, Wetterstrand KA, Abouellleil A, Wollam AM, Buhay CJ, Ding Y, Dugan S, FitzGerald MG, Holder M, Hostetler J, Clifton SW, Allen-Vercoe E, Earl AM, Farmer CN, Liolios K, Surette MG, Xu Q, Pohl C, Wilczek-Boney K, Zhu D (2010) A catalog of reference genomes from the human microbiome. Science 328(5981):994-999

Ng SC, Hart AL, Kamm MA, Stagg AJ, Knight SC (2009) Mechanisms of action of probiotics: recent advances. Inflamm Bowel Dis 15(2):300-310

Nicholson JK, Lindon JC (2008) Systems biology: metabonomics. Nature 455(7216):1054-1056

Nishikawa J, Kudo T, Sakata S, Benno Y, Sugiyama T (2009) Diversity of mucosa-associated microbiota in active and inactive ulcerative colitis. Scand J Gastroenterol 44(2):180-186

O'Hara AM, Shanahan F (2006) The gut flora as a forgotten organ. EMBO Rep 7(7):688-693

Ohge H, Furne JK, Springfield J, Rothenberger DA, Madoff RD, Levitt MD (2005) Association between fecal hydrogen sulfide production and pouchitis. Dis Colon Rectum 48(3):469-475

Onderdonk AB, Dvorak AM, Cisneros RL, McLeod RS, Antionoli D, Silen W, Blair JE, Monahan-Earley RA, Cullen J, Cohen Z (1992) Microbiologic assessment of tissue biopsy samples from ileal pouch patients. J Clin Microbiol 30(2):312-317

Ott SJ, Musfeldt M, Wenderoth DF, Hampe J, Brant O, Fölsch UR, Timmis KN, Schreiber S (2004) Reduction in diversity of the colonic mucosa associated bacterial microflora in patients with active inflammatory bowel disease. Gut 53(5):685-693
Ott SJ, Kühbacher T, Musfeldt M, Rosenstiel P, Hellmig S, Rehman A, Drews O, Weichert W, Timmis KN, Schreiber S (2008) Fungi and inflammatory bowel diseases: alterations of composition and diversity. Scand J Gastroenterol 43(7):831-841

Ouwehand AC, Bergsma N, Parhiala R, Lahtinen S, Gueimonde M, Finne-Soveri H, Strandberg T, Pitkälä K, Salminen S (2008) Bifidobacterium microbiota and parameters of immune function in elderly subjects. FEMS Immunol Med Microbiol 53(1):18-25

Palmer C, Bik EM, DiGiulio DB, Relman DA, Brown PO (2007) Development of the human infant intestinal microbiota. PLoS Biol 5(7):e177

Parracho HM, Bingham MO, Gibson GR, McCartney AL (2005) Differences between the gut microflora of children with autistic spectrum disorders and that of healthy children. J Med Microbiol 54(Pt 10):987-991

Penders J, Thijs C, Vink C, Stelma FF, Snijders B, Kummeling I, van den Brandt PA, Stobberingh EE (2006) Factors influencing the composition of the intestinal microbiota in early infancy. Pediatrics 118(2):511-521

Penders J, Thijs C, van den Brandt PA, Kummeling I, Snijders B, Stelma F, Adams H, van Ree R, Stobberingh EE (2007) Gut microbiota composition and development of atopic manifestations in infancy: the KOALA birth cohort study. Gut 56(5): $661-667$

Pettker CM, Buhimschi IA, Magloire LK, Sfakianaki AK, Hamar BD, Buhimschi CS (2007) Value of placental microbial evaluation in diagnosing intra-amniotic infection. Obstet Gynecol 109(3):739749

Pham M, Lemberg DA, Day AS (2008) Probiotics: sorting the evidence from the myths. Med J Aust 188(5):304-308

Preidis GA, Versalovic J (2009) Targeting the human microbiome with antibiotics, probiotics, and prebiotics: gastroenterology enters the metagenomics era. Gastroenterology 136(6):20152031

Qin J, Li R, Raes J, Arumugam M, Burgdorf KS, Manichanh C, Nielsen T, Pons N, Levenez F, Yamada T, Mende DR, Li J, Xu J, Li S, Li D, Cao J, Wang B, Liang H, Zheng H, Xie Y, Tap J, Lepage P, Bertalan M, Batto JM, Hansen T, Le Paslier D, Linneberg A, Nielsen HB, Pelletier E, Renault P, SicheritzPonten T, Turner K, Zhu H, Yu C, Li S, Jian M, Zhou Y, Li Y, Zhang X, Li S, Qin N, Yang H, Wang J, Brunak S, Doré J, Guarner F, Kristiansen K, Pedersen O, Parkhill J, Weissenbach J, Bork P, Ehrlich SD, Wang J (2010) A human gut microbial gene catalogue established by metagenomic sequencing. Nature 464(7285):59-65

Rajilić-Stojanović M, Smidt H, De Vos WM (2007) Diversity of the human gastrointestinal tract microbiota revisited. Environ Microbiol 9(9):2125-2136

Rijkers GT, Bengmark S, Enck P, Haller D, Herz U, Kalliomäki M, Kudo S, Lenoir-Wijnkoop I, Mercenier A, Myllyluoma E, Rabot S, Rafter J, Szajewska H, Watzl B, Wells J, Wolvers D, Antoine JM (2010) Guidance for substantiating the evidence for beneficial effects of probiotics: current status and recommendations for future research. J Nutr 140(3):671S-676S

Roberfroid M, Gibson GR, Hoyles L, McCartney AL, Rastall R, Rowland I, Wolvers D, Watzl B, Szajewska H, Stahl B, Guarner F, Respondek F, Whelan K, Coxam V, Davicco MJ, Léotoing L, Wittrant Y, Delzenne NM, Cani PD, Neyrinck AM, Meheust A (2010) Prebiotic effects: metabolic and health benefits. Br J Nutr 104(Suppl 2):S1-S63

Rochet V, Rigottier-Gois L, Ledaire A, Andrieux C, Sutren M, Rabot S, Mogenet A, Bresson JL, Cools S, Picard C, Goupil-Feuillerat N, Doré J (2008) Survival of Bifidobacterium animalis DN-173 010 in the faecal microbiota after administration in lyophilised form or in fermented product-a randomised study in healthy adults. J Mol Microbiol Biotechnol 14(1-3):128-136 
Roger LC, McCartney AL (2010) Longitudinal investigation of the faecal microbiota of healthy full-term infants using fluorescence in situ hybridization and denaturing gradient gel electrophoresis. Microbiology 156(Pt 11):3317-3328

Roger LC, Costabile A, Holland DT, Hoyles L, McCartney AL (2010) Examination of faecal Bifidobacterium populations in breast- and formula-fed infants during the first 18 months of life. Microbiology 156(Pt 11):3329-3341

Rooijers K, Kolmeder C, Juste C, Doré J, de Been M, Boeren S, Galan P, Beauvallet C, De Vos WM, Schaap PJ (2011) An iterative workflow for mining the human intestinal metaproteome. BMC Genomics 12(1):6

Rosenfeld G, Bressler B (2010) Mycobacterium avium paratuberculosis and the etiology of Crohn's disease: a review of the controversy from the clinician's perspective. Can J Gastroenterol 24(10):619-624

Ruseler-van Embden JG, Schouten WR, van Lieshout LM (1994) Pouchitis: result of microbial imbalance? Gut 35(5):658-664

Salonen A, De Vos WM, Palva A (2010a) Gastrointestinal microbiota in irritable bowel syndrome: present state and perspectives. Microbiology 156(Pt 11):3205-3215

Salonen A, Nikkila J, Jalanka-Tuovinen J, Immonen O, RajilićStojanović M, Kekkonen RA, Palva A, De Vos WM (2010b) Comparative analysis of fecal DNA extraction methods with phylogenetic microarray: effective recovery of bacterial and archaeal DNA using mechanical cell lysis. J Microbiol Methods 81(2):127-134

Santacruz A, Marcos A, Wärnberg J, Martí A, Martin-Matillas M, Campoy C, Moreno LA, Veiga O, Redondo-Figuero C, Garagorri JM, Azcona C, Delgado M, García-Fuentes M, Collado MC, Sanz Y (2009) Interplay between weight loss and gut microbiota composition in overweight adolescents. Obesity (Silver Spring) 17(10):1906-1915

Santacruz A, Collado MC, García-Valdés L, Segura MT, MartínLagos JA, Anjos T, Martí-Romero M, Lopez RM, Florido J, Campoy C, Sanz Y (2010) Gut microbiota composition is associated with body weight, weight gain and biochemical parameters in pregnant women. Br J Nutr 104(1):83-92

Sanz Y, Sánchez E, Marzotto M, Calabuig M, Torriani S, Dellaglio F (2007) Differences in faecal bacterial communities in coeliac and healthy children as detected by PCR and denaturing gradient gel electrophoresis. FEMS Immunol Med Microbiol 51(3):562-568

Sanz Y, Santacruz A, Gauffin P (2010) Gut microbiota in obesity and metabolic disorders. Proc Nutr Soc 69(3):434-441

Sartor RB (2008) Microbial influences in inflammatory bowel diseases. Gastroenterology 134(2):577-594

Satokari RM, Vaughan EE, Akkermans AD, Saarela M, De Vos WM (2001) Polymerase chain reaction and denaturing gradient gel electrophoresis monitoring of fecal bifidobacterium populations in a prebiotic and probiotic feeding trial. Syst Appl Microbiol 24(2):227-231

Satokari R, Grönroos T, Laitinen K, Salminen S, Isolauri E (2009) Bifidobacterium and lactobacillus DNA in the human placenta. Lett Appl Microbiol 48(1):8-12

Savage DC (1977) Microbial ecology of the gastrointestinal tract. Annu Rev Microbiol 31:107-133

Scanlan PD, Marchesi JR (2008) Micro-eukaryotic diversity of the human distal gut microbiota: qualitative assessment using culture-dependent and -independent analysis of faeces. ISME J 2(12):1183-1193

Scanlan PD, Shanahan F, O'Mahony C, Marchesi JR (2006) Cultureindependent analyses of temporal variation of the dominant fecal microbiota and targeted bacterial subgroups in Crohn's disease. J Clin Microbiol 44(11):3980-3988

Scanlan PD, Shanahan F, Clune Y, Collins JK, O'Sullivan GC, O'Riordan M, Holmes E, Wang Y, Marchesi JR (2008) Culture- independent analysis of the gut microbiota in colorectal cancer and polyposis. Environ Microbiol 10(3):789-798

Schiffrin EJ, Morley JE, Donnet-Hughes A, Guigoz Y (2010) The inflammatory status of the elderly: the intestinal contribution. Mutat Res 690(1-2):50-56

Schippa S, Iebba V, Barbato M, Di Nardo G, Totino V, Checchi MP, Longhi C, Maiella G, Cucchiara S, Conte MP (2010) A distinctive 'microbial signature' in celiac pediatric patients. BMC Microbiol 10:175

Schwiertz A, Taras D, Schäfer K, Beijer S, Bos NA, Donus C, Hardt PD (2010) Microbiota and SCFA in lean and overweight healthy subjects. Obesity (Silver Spring) 18(1):190-195

Sekirov I, Russell SL, Antunes LC, Finlay BB (2010) Gut microbiota in health and disease. Physiol Rev 90(3):859-904

Seksik P, Rigottier-Gois L, Gramet G, Sutren M, Pochart P, Marteau P, Jian R, Doré J (2003) Alterations of the dominant faecal bacterial groups in patients with Crohn's disease of the colon. Gut 52(2):237-242

Shen XJ, Rawls JF, Randall T, Burcal L, Mpande CN, Jenkins N, Jovov B, Abdo Z, Sandler RS, Keku TO (2010) Molecular characterization of mucosal adherent bacteria and associations with colorectal adenomas. Gut Microbes 1(3):138-147

Sjögren YM, Jenmalm MC, Bottcher MF, Björkstén B, SverremarkEkström E (2009) Altered early infant gut microbiota in children developing allergy up to 5 years of age. Clin Exp Allergy 39(4):518-526

Snel J, Vissers YM, Smit BA, Jongen JM, van der Meulen ET, Zwijsen R, Ruinemans-Koerts J, Jansen AP, Kleerebezem M, Savelkoul HF (2010) Strain-specific immunomodulatory effects of Lactobacillus plantarum strains on birch-pollen-allergic subjects out of season. Clin Exp Allergy 41(2):232-242

Sokol H, Seksik P (2010) The intestinal microbiota in inflammatory bowel diseases: time to connect with the host. Curr Opin Gastroenterol 26(4):327-331

Sokol H, Seksik P, Rigottier-Gois L, Lay C, Lepage P, Podglajen I, Marteau P, Doré J (2006) Specificities of the fecal microbiota in inflammatory bowel disease. Inflamm Bowel Dis 12(2):106-111

Sokol H, Pigneur B, Watterlot L, Lakhdari O, Bermúdez-Humáran LG, Gratadoux JJ, Blugeon S, Bridonneau C, Furet JP, Corthier G, Grangette C, Vasquez N, Pochart P, Trugnan G, Thomas G, Blottière HM, Doré J, Marteau P, Seksik P, Langella P (2008) Faecalibacterium prausnitzii is an anti-inflammatory commensal bacterium identified by gut microbiota analysis of Crohn disease patients. Proc Natl Acad Sci USA 105(43):16731-16736

Sokol H, Seksik P, Furet JP, Firmesse O, Nion-Larmurier I, Beaugerie L, Cosnes J, Corthier G, Marteau P, Doré J (2009) Low counts of Faecalibacterium prausnitzii in colitis microbiota. Inflamm Bowel Dis 15(8):1183-1189

Song Y, Liu C, Finegold SM (2004) Real-time PCR quantitation of clostridia in feces of autistic children. Appl Environ Microbiol 70(11):6459-6465

Stewart JA, Chadwick VS, Murray A (2005) Investigations into the influence of host genetics on the predominant eubacteria in the faecal microflora of children. J Med Microbiol 54(Pt 12): 1239-1242

Štšepetova J, Sepp E, Julge K, Vaughan E, Mikelsaar M, De Vos WM (2007) Molecularly assessed shifts of Bifidobacterium ssp. and less diverse microbial communities are characteristic of 5-yearold allergic children. FEMS Immunol Med Microbiol 51(2): 260-269

Suzuki S, Shimojo N, Tajiri Y, Kumemura M, Kohno Y (2007) Differences in the composition of intestinal Bifidobacterium species and the development of allergic diseases in infants in rural Japan. Clin Exp Allergy 37(4):506-511

Swidsinski A, Ladhoff A, Pernthaler A, Swidsinski S, LoeningBaucke V, Ortner M, Weber J, Hoffmann U, Schreiber S, Dietel 
M, Lochs H (2002) Mucosal flora in inflammatory bowel disease. Gastroenterology 122(1):44-54

Swidsinski A, Weber J, Loening-Baucke V, Hale LP, Lochs H (2005) Spatial organization and composition of the mucosal flora in patients with inflammatory bowel disease. J Clin Microbiol 43(7):3380-3389

Takaishi H, Matsuki T, Nakazawa A, Takada T, Kado S, Asahara T, Kamada N, Sakuraba A, Yajima T, Higuchi H, Inoue N, Ogata $\mathrm{H}$, Iwao $\mathrm{Y}$, Nomoto K, Tanaka R, Hibi T (2008) Imbalance in intestinal microflora constitution could be involved in the pathogenesis of inflammatory bowel disease. Int J Med Microbiol 298(5-6):463-472

Tana C, Umesaki Y, Imaoka A, Handa T, Kanazawa M, Fukudo S (2010) Altered profiles of intestinal microbiota and organic acids may be the origin of symptoms in irritable bowel syndrome. Neurogastroenterol Motil 22(5):512-519

Tannock GW, Munro K, Harmsen HJ, Welling GW, Smart J, Gopal PK (2000) Analysis of the fecal microflora of human subjects consuming a probiotic product containing Lactobacillus rhamnosus DR20. Appl Environ Microbiol 66(6):2578-2588

Tap J, Mondot S, Levenez F, Pelletier E, Caron C, Furet JP, Ugarte E, Muñoz-Tamayo R, Paslier DL, Nalin R, Doré J, Leclerc M (2009) Towards the human intestinal microbiota phylogenetic core. Environ Microbiol 11(10):2574-2584

Tasse L, Bercovici J, Pizzut-Serin S, Robe P, Tap J, Klopp C, Cantarel BL, Coutinho PM, Henrissat B, Leclerc M, Doré J, Monsan P, Remaud-Simeon M, Potocki-Veronese G (2010) Functional metagenomics to mine the human gut microbiome for dietary fiber catabolic enzymes. Genome Res 20(11):1605-1612

Tiihonen K, Ouwehand AC, Rautonen N (2010) Human intestinal microbiota and healthy ageing. Ageing Res Rev 9(2):107-116

Timmerman HM, Koning CJ, Mulder L, Rombouts FM, Beynen AC (2004) Monostrain, multistrain and multispecies probiotics-A comparison of functionality and efficacy. Int J Food Microbiol 96(3):219-233

Treem WR, Ahsan N, Kastoff G, Hyams JS (1996) Fecal short-chain fatty acids in patients with diarrhea-predominant irritable bowel syndrome: in vitro studies of carbohydrate fermentation. J Pediatr Gastroenterol Nutr 23(3):280-286

Turnbaugh PJ, Ley RE, Mahowald MA, Magrini V, Mardis ER, Gordon JI (2006) An obesity-associated gut microbiome with increased capacity for energy harvest. Nature 444(7122):10271031

Turnbaugh PJ, Hamady M, Yatsunenko T, Cantarel BL, Duncan A, Ley RE, Sogin ML, Jones WJ, Roe BA, Affourtit JP, Egholm M, Henrissat B, Heath AC, Knight R, Gordon JI (2009) A core gut microbiome in obese and lean twins. Nature 457(7228):480-484

Vaahtovuo J, Munukka E, Korkeamäki M, Luukkainen R, Toivanen P (2008) Fecal microbiota in early rheumatoid arthritis. J Rheumatol 35(8):1500-1505

Vael C, Desager K (2009) The importance of the development of the intestinal microbiota in infancy. Curr Opin Pediatr 21(6):794800

Van Baarlen P, Troost FJ, van Hemert S, van der Meer C, De Vos WM, de Groot PJ, Hooiveld GJ, Brummer RJ, Kleerebezem M (2009) Differential NF-kappaB pathways induction by Lactobacillus plantarum in the duodenum of healthy humans correlating with immune tolerance. Proc Natl Acad Sci USA 106(7):23712376

Van den Bogert B, De Vos WM, Zoetendal EG, Kleerebezem M (2011) Microarray analysis and barcoded pyrosequencing provide consistent microbial profiles depending on the source of human intestinal samples. Appl Environ Microbiol. 77(6): 2071-2080

Van Hemert S, Meijerink M, Molenaar D, Bron PA, De Vos P, Kleerebezem M, Wells JM, Marco ML (2010) Identification of
Lactobacillus plantarum genes modulating the cytokine response of human peripheral blood mononuclear cells. BMC Microbiol 10:293

Van Tongeren SP, Slaets JP, Harmsen HJ, Welling GW (2005) Fecal microbiota composition and frailty. Appl Environ Microbiol 71(10):6438-6442

Vanhoutte T, Huys G, Brandt E, Swings J (2004) Temporal stability analysis of the microbiota in human feces by denaturing gradient gel electrophoresis using universal and group-specific 16S rRNA gene primers. FEMS Microbiol Ecol 48(3):437-446

Vanhoutte T, De Preter V, De Brandt E, Verbeke K, Swings J, Huys $G$ (2006) Molecular monitoring of the fecal microbiota of healthy human subjects during administration of lactulose and Saccharomyces boulardii. Appl Environ Microbiol 72(9):5990_ 5997

Veiga P, Gallini CA, Beal C, Michaud M, Delaney ML, DuBois A, Khlebnikov A, van Hylckama Vlieg JE, Punit S, Glickman JN, Onderdonk A, Glimcher LH, Garrett WS (2010) Bifidobacterium animalis subsp. lactis fermented milk product reduces inflammation by altering a niche for colitogenic microbes. Proc Natl Acad Sci USA 107(42):18132-18137

Verberkmoes NC, Russell AL, Shah M, Godzik A, Rosenquist M, Halfvarson J, Lefsrud MG, Apajalahti J, Tysk C, Hettich RL, Jansson JK (2009) Shotgun metaproteomics of the human distal gut microbiota. ISME J 3(2):179-189

Vissers YM, Snel J, Zuurendonk PF, Smit BA, Wichers HJ, Savelkoul HF (2010) Differential effects of Lactobacillus acidophilus and Lactobacillus plantarum strains on cytokine induction in human peripheral blood mononuclear cells. FEMS Immunol Med Microbiol 59(1):60-70

Vissers YM, Snel J, Zuurendonk PF, Kleerebezem M, Wichers HJ, Savelkoul HF (2011) Lactobacillus strains differentially modulate cytokine production by hPBMC from pollen-allergic patients. FEMS Immunol Med Microbiol 61(1):28-40

Vitali B, Ndagijimana M, Cruciani F, Carnevali P, Candela M, Guerzoni ME, Brigidi P (2010) Impact of a synbiotic food on the gut microbial ecology and metabolic profiles. BMC Microbiol 10:4

Vrieze A, Holleman F, Zoetendal EG, De Vos WM, Hoekstra JB, Nieuwdorp M (2010) The environment within: how gut microbiota may influence metabolism and body composition. Diabetologia 53(4):606-613

Walker AW, Ince J, Duncan SH, Webster LM, Holtrop G, Ze X, Brown D, Stares MD, Scott P, Bergerat A, Louis P, McIntosh F, Johnstone AM, Lobley GE, Parkhill J, Flint HJ (2011a) Dominant and diet-responsive groups of bacteria within the human colonic microbiota. Isme J 5(2):220-230

Walker AW, Sanderson JD, Churcher C, Parkes GC, Hudspith BN, Rayment N, Brostoff J, Parkhill J, Dougan G, Petrovska L (2011b) High-throughput clone library analysis of the mucosaassociated microbiota reveals dysbiosis and differences between inflamed and non-inflamed regions of the intestine in inflammatory bowel disease. BMC Microbiol 11(1):7

Wang X, Heazlewood SP, Krause DO, Florin TH (2003) Molecular characterization of the microbial species that colonize human ileal and colonic mucosa by using $16 \mathrm{~S}$ rDNA sequence analysis. J Appl Microbiol 95(3):508-520

Wang M, Ahrné S, Jeppsson B, Molin G (2005) Comparison of bacterial diversity along the human intestinal tract by direct cloning and sequencing of 16S rRNA genes. FEMS Microbiol Ecol 54(2):219-231

Wang M, Karlsson C, Olsson C, Adlerberth I, Wold AE, Strachan DP, Martricardi PM, Åberg N, Perkin MR, Tripodi S, Coates AR, Hesselmar B, Saalman R, Molin G, Ahrné S (2008) Reduced diversity in the early fecal microbiota of infants with atopic eczema. J Allergy Clin Immunol 121(1):129-134 
Wang Y, Hoenig JD, Malin KJ, Qamar S, Petrof EO, Sun J, Antonopoulos DA, Chang EB, Claud EC (2009) 16S rRNA gene-based analysis of fecal microbiota from preterm infants with and without necrotizing enterocolitis. ISME J 3(8):944-954

Wang Y, Devkota S, Musch MW, Jabri B, Nagler C, Antonopoulos DA, Chervonsky A, Chang EB (2010) Regional mucosaassociated microbiota determine physiological expression of TLR2 and TLR4 in murine colon. PLoS One 5(10):e13607

Watanabe S, Narisawa Y, Arase S, Okamatsu H, Ikenaga T, Tajiri Y, Kumemura M (2003) Differences in fecal microflora between patients with atopic dermatitis and healthy control subjects. J Allergy Clin Immunol 111(3):587-591

Weichselbaum E (2010) Potential benefits of probiotics-main findings of an in-depth review. Br J Community Nurs 15(3):110, 112,114

Willing B, Halfvarson J, Dicksved J, Rosenquist M, Järnerot G, Engstrand L, Tysk C, Jansson JK (2009) Twin studies reveal specific imbalances in the mucosa-associated microbiota of patients with ileal Crohn's disease. Inflamm Bowel Dis 15(5):653-660

Wong JM, de Souza R, Kendall CW, Emam A, Jenkins DJ (2006) Colonic health: fermentation and short chain fatty acids. J Clin Gastroenterol 40(3):235-243

Woodmansey EJ (2007) Intestinal bacteria and ageing. J Appl Microbiol 102(5):1178-1186

Wu X, Ma C, Han L, Nawaz M, Gao F, Zhang X, Yu P, Zhao C, Li L, Zhou A, Wang J, Moore JE, Millar BC, Xu J (2010) Molecular characterisation of the faecal microbiota in patients with type II diabetes. Curr Microbiol 61(1):69-78

Zella GC, Hait EJ, Glavan T, Gevers D, Ward DV, Kitts CL, Korzenik JR (2011) Distinct microbiome in pouchitis compared to healthy pouches in ulcerative colitis and familial adenomatous polyposis. Inflamm Bowel Dis 17(5):1092-1100

Zhang H, DiBaise JK, Zuccolo A, Kudrna D, Braidotti M, Yu Y, Parameswaran P, Crowell MD, Wing R, Rittmann BE, Krajmalnik-
Brown R (2009) Human gut microbiota in obesity and after gastric bypass. Proc Natl Acad Sci USA 106(7):2365-2370

Zivkovic AM, German JB, Lebrilla CB, Mills DA (2010) Microbes and Health Sackler Colloquium: Human milk glycobiome and its impact on the infant gastrointestinal microbiota. Proc Natl Acad Sci USA. Epub

Zoetendal EG, Akkermans AD, De Vos WM (1998) Temperature gradient gel electrophoresis analysis of 16S rRNA from human fecal samples reveals stable and host-specific communities of active bacteria. Appl Environ Microbiol 64(10):3854-3859

Zoetendal EG, Akkermans ADL, Akkermans-Van Vliet WM, de Visser JAGM, De Vos WM (2001) The host genotype affects the bacterial community in the human gastrointestinal tract. Microbial Ecol Health Dis 13(3):129-134

Zoetendal EG, von Wright A, Vilpponen-Salmela T, Ben-Amor K, Akkermans AD, De Vos WM (2002) Mucosa-associated bacteria in the human gastrointestinal tract are uniformly distributed along the colon and differ from the community recovered from feces. Appl Environ Microbiol 68(7):3401-3407

Zoetendal EG, Vaughan EE, De Vos WM (2006) A microbial world within us. Mol Microbiol 59(6):1639-1650

Zoetendal EG, Rajilić-Stojanović M, De Vos WM (2008) Highthroughput diversity and functionality analysis of the gastrointestinal tract microbiota. Gut 57(11):1605-1615

Zoetendal EG, Raes J, Van den Bogert B, Arumugam M, Booijink CCGM, Troost FJ, Bork P, Wels M, De Vos WM, Kleerebezem M (2011) Metagenomic and metatranscriptomic analyses of the human small intestinal microbiota reveals a community that is driven by fast uptake and conversion of carbohydrates. Submitted for publication

Zwielehner J, Liszt K, Handschur M, Lassl C, Lapin A, Haslberger AG (2009) Combined PCR-DGGE fingerprinting and quantitative-PCR indicates shifts in fecal population sizes and diversity of Bacteroides, bifidobacteria and Clostridium cluster IV in institutionalized elderly. Exp Gerontol 44(6-7):440-446 